
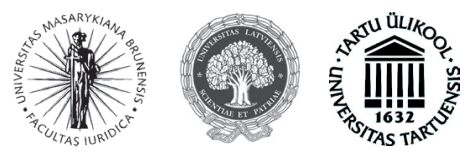

ISSN 1392-6195 (print) ISSN 2029-2058 (online) JURISPRUDENCIJA JURISPRUDENCE 2013, 20(3), p. 855-899.

\title{
EUROPOS ŽMOGAUS TEISIŲ KONVENCIJOS TEIKIAMA APSAUGA - OAZĖ PRIEGLOBSČIO PRAŠYTOJAMS EUROPOJE?
}

\author{
Lyra Jakulevičiené, Vladimiras Siniovas \\ Mykolo Romerio universiteto Teisès fakulteto \\ Tarptautinès ir Europos Sajungos teisès institutas \\ Ateities g. 20, LT-08303 Vilnius, Lietuva \\ Telefonas (+370 5) 2714669
}

Elektroninis paštas: lyra.jakuleviciene@gmail.com; vsiniovas@gmail.com

Pateikta 2013 m. liepos 31 d., parengta spausdinti 2013 m. rugpjūčio 23 d.

doi:10.13165/JUR-13-20-3-03

Anotacija. Nors Žmogaus teisiu ir pagrindiniu laisviu apsaugos konvencija tiesiogiai negina prieglobsčio prašytoju teisiu, Europos Žmogaus Teisiu Teismas priemè nemažai sprendimu, kuriuose konstatuojami tokių asmenu teisiu pažeidimai. Tuo pat metu vystosi ir Europos Sajungos Teisingumo Teismo praktika prieglobsčio bylose. Pastebima tendencija, kad šis Teismas referuoja i Strasbūro teismo jurisprudencija ir ja remiasi. Kita vertus, Žmogaus Teisiu Teismas yra priemęs keleta sprendimu, susijusiu su ES prieglobsčio teise. Taigi neabejotinai tarp šiu teisiu gynimo mechanizmu prieglobsčio bylose formuojasi tam tikras ryšys. Straipsnio autoriai analizuoja Žmogaus teisiu ir pagrindiniu laisviu apsaugos konvencijos teikiama apsauga prieglobsčio prašytojams lygindami ja su naujausia Europos Sajungos Teisingumo Teismo jurisprudencija prieglobsčio bylose, siekdami nustatyti, kuris iš šiu mechanizmu yra palankesnis prieglobsčio prašytojams bei kokie yra ju trükumai.

Reikšminiai žodžiai: prieglobstis, Europos žmogaus teisiu konvencija, prašymas pateikti prejudicini sprendima, Chartija, Europos Sajungos prieglobsčio teisynas, Europos Žmogaus Teisiu Teismas, Europos Sajungus Teisingumo Teismas. 


\section{Ivadas}

Žmogaus teisių ir pagrindinių laisvių apsaugos konvencija (toliau - EŽTK, konvencija) nėa specialusis prieglobsčio prašytojų teisių gynimą užtikrinantis susitarimas. Toks susitarimas yra $1951 \mathrm{~m}$. Jungtinių Tautų konvencija dèl pabėgèlių statuso (toliau 1951 m. konvencija). Tačiau šios konvencijos problema yra tai, kad ji nenumato veiksmingo prieglobsčio prašytojų ir pabėgèlių teisių gynimo mechanizmo. Todèl natūralu, kad asmenys ir teisininkai ieško kitų prieglobsčio prašytojų teisių gynimo būdų. Nors EŽTK nerasime nè vieno straipsnio, kuriame būtų ịtvirtintos būtent šių asmenų teisès, per pastaruosius 20 metų Europos Žmogaus Teisių Teismas (toliau - EŽTT, Teismas) prièmė nemažai sprendimų, kuriuose konstatuojami prieglobsčio prašytojų teisių pažeidimai pagal konvencijos 3, 5, 8, 13 straipsnį, 7 protokolo 1 straipsnị ir 4 protokolo 4 straipsnị. Prieglobsčio prašytojų peticijas dẻl ịvairių EŽTK straipsnių pažeidimo EŽTT nagrinèja jau gerą dvidešimtmetị, tačiau pastaruoju metu buvo priimti sprendimai bylose, kuriose keliami itin aktualūs ir jautrūs valstybèms klausimai (M. S. S. prieš Graikija ir Belgija, Hirsi Jamaa prieš Italija ir kt.). Intensyviai vystosi ir Europos Sajungos Teisingumo Teismo (toliau - ES Teismas, ESTT) jurisprudencija pagal prejudiciniu sprendimų procedūrą prieglobsčio bylose. Pastebima tendencija, kad ESTT referuoja i EŽTK jurisprudenciją ir ja remiasi. Kita vertus, EŽTT yra prièmęs keletą sprendimų, kuriuose sprendžiamas ES prieglobsčio teisès taikymo klausimas. Taigi neabejotinai tarp šių teisių gynimo mechanizmų prieglobsčio bylose formuojasi tam tikras ryšys, tačiau jo pobūdis kol kas neaiškus. Šiuo metu individualios peticijos teisė yra galima tik pagal EŽTK mechanizmą, bet ne pagal ES teisių gynimo mechanizmą, tačiau teisininkai bei teismai ir dabar gali aktyviau išnaudoti ES teikiamas galimybes.

Straipsnio tikslas - ịvertinti Europos žmogaus teisių ir pagrindinių laisvių apsaugos konvencijos teikiamą apsaugą prieglobsčio prašytojams lyginant ją su naujausia Europos Sajungos Teisingumo Teismo jurisprudencija prieglobsčio bylose. Straipsnyje keliami šie uždaviniai, apibrèžiantys ir straipsnio struktūrą:

1. Remiantis EŽTT jurisprudencija išnagrinèti, kokios prieglobsčio prašytojų teisès gali būti veiksmingai ginamos šiuo Europos tarybos mechanizmu.

2. Nustatyti, kokias prieglobsčio prašytojams aktualių pagrindinių teisių gynimo galimybes siūlo ES teisès sistema, atsižvelgiant ị besivystančią ESTT praktiką taikant ES prieglobsčio teisyną, bei įvertinti jos santykị su EŽTT jurisprudencija.

3. Nustatyti, kuo Europos Tarybos teisių gynimo sistema yra palankesnė prieglobsčio prašytojams nei Europos Sajungos teisių gynimo sistema bei kokie jos trūkumai.

Straipsnyje pateikiamo tyrimo objektas yra prieglobsčio prašytojų teisių gynimas pagal EŽTK ir ES teisių gynimo mechanizmą. Temai atskleisti straipsnyje daugiausiai taikytas lyginamasis, empirinis ir sisteminès analizės metodai. Straipsnyje išnagrinèti ir apibendrinti pagrindiniai EŽTT ir ESTT sprendimai prieglobsčio bylose. Šią temą analizavo nemažai užsienio autorių (pvz., Nuala Mole, Helene Lambert, Hemme Battjes ir kt.). Tačiau dauguma autorių prieglobsčio prašytojų teisių gynimo galimybes nagrinèja 
vien pagal EŽTK arba vien pagal ES teisių gynimo mechanizmą, tačiau mažai analizuoja Strasbūro ir Liuksemburgo jurisdikcijų sąveiką. Kai kurie užsienio ir Lietuvos autoriai tiria būtent ši aspektą (pvz., Danutė Jočienė, Marija Anciuvienè, Saulius Katuoka, Francis G. Jacobs, Leonard F. M. Besselink ir kt.), tačiau nenagrinèja šios sąveikos būtent per prieglobsčio teisès prizmę. Hemme Battjes ištyrė ES prieglobsčio teisès ir tarptautinès teisès santykị, tačiau jo 2006 m. išleistas darbas neapima ESTT ir naujausios EŽTT praktikos šioje srityje. Lyra Jakulevičienè straipsnyje „Pirmujų ES Teisingumo Teismo sprendimų prieglobsčio bylose pamokos“ 2012 m. nagrinejjo ESTT sprendimus, tačiau tik tam tikroje srityje ir tiesiogiai nelyginant su EŽTT. Vienas naujausių praktinių leidinių šia tema yra 2013 m. išleistas Europos teisès prieglobsčio, sienų ir imigracijos srityse vadovas ${ }^{1}$, kuriame pateikiama EŽTT ir ESTT analizè. Vis dèlto šis vadovas yra daugiau pažintinio, apžvalginio pobūdžio. Taigi šis straipsnis siūlo detalią naujausios EŽTT ir ESTT jurisprudencijos analizę lyginamuoju aspektu ir esminę problematiką, kylančią šiose jurisdikcijose ir jų sandūroje. Straipsnis gali būti naudingas teisininkams, atstovaujantiems prieglobsčio prašytojams, tarptautinę viešają ar tarptautinę arba ES prieglobsčio teisę studijuojantiems studentams bei institucijoms ir teismams, nagrinèjantiems prieglobsčio prašytojų bylas Lietuvoje bei sprendžiantiems prieglobsčio prašytojų apsaugos problemas.

\section{EŽTK teikiamos apsaugos prieglobsčio prašytojams apimtis}

Šiame skyriuje remiantis Europos Žmogaus Teisių Teismo jurisprudencija nagrinejjama, kokios prieglobsčio prašytojų teisès gali būti veiksmingai ginamos pasitelkiant ši Europos tarybos mechanizmą. EŽTK nereguliuoja ,ekstradicijos, išsiuntimo ar prieglobsčio teisès“", taip pat nei pati konvencija, nei jos protokolai tiesiogiai ar netiesiogiai nepripažista teisès ị prieglobstị ${ }^{2}$. Tačiau valstybės, igyvendindamos savo teisę kontroliuoti užsieniečių atvykimą, gyvenimą ir išsiuntimą iš savo teritorijos ,privalo užtikrinti, kad nebūtų pažeistos konvencijos garantuojamos teisès ${ }^{63}$. Prieglobsčio prašytojo ar pabėgèlio išsiuntimo atveju gali iškilti konvencijos 3 straipsnio pažeidimo pavojus, jei yra rimtų priežasčių manyti, kad išsiunčiamas asmuo patirs 3 straipsniu draudžiamą elgesị. Tokiais atvejais valstybių ịsipareigojimas reiškia, kad asmuo negali būti išsiųstas iš priimančiosios šalies ${ }^{4}$. Prieglobsčio prašytojams taip pat aktualus konvencijos 5 straipsnis. Jei jie atvyksta neturẻdami leidimo įvažiuoti ị šalị ar kelionès dokumentų, valstybès vis dar neretai taiko sulaikymo priemones. Prieglobsčio

1 Handbook on European law relating to asylum, borders and immigration, European Court of Human Rights and EU Fundamental Rights“'Agency. Luxembourg, 2013.

2 Salah Sheekh v. The Netherlands, Appl. No. 1948/04, European Court of Human Rights, Judgement, 11 January 2007, 35 pnk., Ahmed v. Austria, Appl. No. 71/1995/577/663, European Court of Human Rights, Judgement, 17 December 1996, 38 pnk.

3 Vilvarajah and Others v. the United Kingdom, Appl. No. 45/1990/236/302-306, European Court of Human Rights, Judgement, 26 September 1991, 103 pnk.

4 Saadiv. Italy, Appl. No. 37201/06, European Court of Human Rights, Judgement, 28 February 2008, 125 pnk. 
prašytojams teisè i šeimos susijungimą tarptautinejje teisèje nėra pripažįstama, nes jų bylos dèl prieglobsčio dar tik nagrinèjamos, tačiau suteikus prieglobstị pabėgèliams gali būti aktualu pasikviesti atvykti kartu gyventi šeimos narius, kurie galbūt liko kilmès valstybejje, kur gresia pavojai, arba pasimetė kelionès metu ir šiuo metu yra kitoje valstybejje. Nors pabėgèlių bylų pagal konvencijos 8 straipsnị nėra daug, jiems gali būti aktuali konvencijos apsauga, numatanti šeimos teisių gynimą. Pastaruoju metu vis dažniau iškyla konvencijos 13 straipsnio taikymo prieglobsčio prašytojams klausimai, kadangi valstybėse esančios teisinès gynybos priemonės (ypač galimybė apskųsti prieglobsčio prašytojo, kuriam atsisakyta suteikti prieglobstị, išsiuntimą arba prieglobsčio nesuteikimo sprendimą) neretai nėra veiksmingos. EŽTK yra taikoma prieglobsčio prašytojams ir pabėgèliams bendrais pagrindais, t. y. pagal konvencijos 1 straipsnic, nes jie yra valstybès teritorijoje arba jurisdikcijoje. Pavyzdžiui, $2010 \mathrm{~m}$. byloje Iskandarov prieš Rusiją Teismas pabrěžè, kad atsakomybė pagal konvenciją kyla ne dèl veiksmų, kurie vykdomi už jurisdikcijos ribų, bet valstybei priskiriamų veiksmų, kurie turi tiesioginę ịtaką tam, kad asmuo susidurs su netinkamu elgesiu, todèl vyriausybès argumentai, kad veiksmai nepatenka ị teritorinę jurisdikciją ekstradicijos atveju, turi būti atmesti ${ }^{5}$. Kadangi prieglobsčio prašytojų ir pabėgèlių situacija yra specifinè, tais atvejais, kai jie dar nėra valstybės teritorijoje, konvencija jiems taikoma valstybès jurisdikcijos pagrindu. Jurisdikcijos klausimas buvo iškilęs vienoje iš naujausių bylų Hirsi Jamaa ir kiti prieš Italiją (2012 m.). Šioje byloje Teismas nusprendè, kad Italijos policijos veiksmai sulaikant Somalio ir Eritrejos migrantus jūroje, keliaujančius iš Libijos, ir jų grąžinimas ị tranzito ar kilmès valstybes neatsižvelgiant ị ten gresiančius pavojus, yra Italijos jurisdikcijos vykdymas ir nèra suderinamas su konvencijos 3 straipsnio isipareigojimais ${ }^{6}$.

\subsection{Apsauga nuo individualaus ir kolektyvinio išsiuntimo}

Šiame poskyryje nagrinèjami ne visi, o tik probleminiai apsaugos nuo išsiuntimo taikymo aspektai, tokie kaip: pavojaus individualizacijos reikalavimo taikymas, apsaugos absoliutumo kvestionavimas ir diplomatinių garantijų taikymas, „Dublino“ bylos bei asmens statuso sustabdžius išsiuntimą klausimas.

Pirmą kartą konvencijos 3 straipsnio pažeidimas išsiuntimo byloje buvo nustatytas dar 1989 m. byloje Soering prieš Jungtinę Karalystę ${ }^{7}$, nors ji ir nebuvo susijusi su prieglobsčio prašytojais. Šiuo metu EŽTT praktika yra visiškai susiformavusi dèl to, kad asmens išsiuntimas pažeis konvenciją tais atvejais, kai valstybėje, ị kurią asmuo išsiunčiamas, jam gresia kankinimai ar kitoks nežmoniškas elgesys (toliau-netinkamas elgesys) ${ }^{8}$.

Iskandarov v. Russia, Appl. No. 17185/05, European Court of Human Rights, Judgement, 23 September 2010, 120 pnk.

6 Hirsi Jamaa and Others v. Italy, Appl. No. 27765/09, European Court of Human Rights, Judgement, 23 February 2012, 82 pnk.

$7 \quad$ Soering $v$. the United Kingdom, Judgment of 7 July 1989, Series A No. 161, 90-91 pnk.

8 Pavyzdžiui, Vilvarajah and Others v. the United Kingdom, 103 pnk.; H. L. R. v. France, Judgment of 29 April 1997, Reports 1997-III, 34 pnk.; Jabari v. Turkey, Appl. No. 40035/98, European Court of Human Rights, Judgement, 11 July 2000, 38 pnk.; Salah Sheekh v. the Netherlands, 135 pnk., Saadi v. Italy, 152 pnk. 
Išskiriamos trys šio straipsnio taikymo sąlygos: a) turi būti pasiektas minimalus veiksmų sunkumo laipsnis (angl. severity) (pvz., užmėtymas akmenimis); b) turi būti realus pavojus, kad asmuo patirs netinkamą elgesị (nepakanka ,vien tik galimybès“, angl. mere possibility); c) turi būti esminès priežastys tikèti, kad asmuo gali patirti netinkamą elgesi (nėra reikalaujama įrodyti pavojų) ${ }^{9}$. Nagrinėdamas bylas dèl išsiuntimo, kuriose gali būti pažeistas konvencijos 3 straipsnis, Teismas vertina tiek bendrą žmogaus teisių padėtị šalyje, tiek ir ypatingas pareiškèjo aplinkybes ${ }^{10}$. Reikalaujama, kad pareiškejjas nurodytų rimtas priežastis, dèl ko jam gresia netinkamas elgesys ar bausmé valstybeje, i kurią jis išsiunčiamas ${ }^{11}$. Konvencijos 3 straipsnio kontekste aktualus ịrodinejjimo, kad asmeniui gresia netinkamas elgesys, klausimas. Pasakytina, kad griežti ịrodinejjimo reikalavimai yra bene pagrindinè kliūtis daugeliui prieglobsčio prašytojų ginti savo teises pagal ši straipsnị. Šiuo požiūriu Teismo pozicija palaipsniui kinta. Vienas iš svarbiausių i̇rodinėjimo aspektų yra Vilvarajah prieš Jungtine Karalystę byloje dar $1991 \mathrm{~m}$. išvystytas ,individualizacijos“" reikalavimas. Jis reiškia, kad asmuo turi būti individualiai paveiktas netinkamo elgesio pavojaus ir kad jo padètis turi būti kitokia lyginant su visais kitais asmenimis toje šalyje, kad būtų galima pripažinti individualios grèsmès jo atveju buvimą. Tačiau pažymėtina, kad Teismas pastarojo meto bylose (pvz., Salah Sheek prieš Nyderlandus, 2007 m., Sufi ir Elmi prieš Jungtine Karalystę, 2011 m. ir kt.) ši kriterijų taiko nebe taip griežtai. Pastarojo meto bylose teismas nagrinèjo individualios grèsmès ir bendro pobūdžio pavojų santykị (angl. individualisation vs. general violence). Bylų analizė rodo, kad: pirma, $1991 \mathrm{~m}$. Teismas reikalavo ịrodyti, kad pareiškèjo padètis yra blogesnè nei kitų, ir buvo būtina identifikuoti specifinius pareiškèjo bruožus, aplinkybes, išskiriančias ji iš kitų asmenų toje šalyje ${ }^{12}$, o vèliau Teismas nebereikalavo specialiujų bruožų, jei pareiškèjas priklausė grupei, kuriai grèsė netinkamas elgesys ${ }^{13}$. Teismo nuomone, tais atvejais, kai pareiškèjas teigia, kad yra narys grupès, su kuria sistemingai elgiamasi netinkamai 3 straipsnio prasme, šio straipsnio apsauga taikoma, kai asmuo įrodo, kad yra rimtos priežastys tikèti, jog tokia praktika egzistuoja ${ }^{14}$. Šiomis aplinkybemis Teismas nereikalauja, kad pareiškèjas nurodytų papildomas išskiriančias savybes, jei dẻl to apsauga pagal 3 straipsnị taptų iliuzine. Tokiu atveju būtų atsižvelgiama ị pareiškejjo pareiškimus ir

9 Maurer-Kober, B. Presentation at the EJTN Seminar „Migration and Asylum Law“, Session II: The European Convention on Human Rights Articles 3 and 8 Overview of the ECHR and CJEU jurisprudence, 11-12 September 2012, Bucharest [interaktyvus]. [Žiūrèta 2013-07-23]. <http://www.ejtn.net/Documents/ About\%20EJTN/Independent\%20Seminars/Session_II_ECHR_Article_3_and_8_WINTER_Karin_ MAURER-KOBER_Bettina_Seminar_Migration_and_Asylum_Law_1 1 _ 12 _September_2012.pdf $>$, p. 2-5.

10 Labsi v. Slovakia, Appl. No. 33809/08, European Court of Human Rights, Judgement, 15 May 2012,119 pnk.

11 M. S. S. v. Belgium and Greece, Appl. No. 30696/09, European Court of Human Rights, Judgement, 21 January 2011, 365 pnk.

12 Vilvarajah and Others $v$. the United Kingdom, 112 pnk.

13 Salah Sheek v. Netherlands, 148 pnk.

14 Abdolkhani and Karimnia v. Turkey, Appl. No. 30471/08, European Court of Human Rights, Judgement, 22 September 2009, 75 pnk., Saadi v. Italy, 132 pnk. 
informaciją apie tokios grupès padètị kilmès valstybëje $\mathrm{e}^{15}$. Viename iš naujausių sprendimų - Sidikovy prieš Rusiją (2013 m. birželio 20 d.) Teismas nagrinèjo bendrą žmogaus teisių padètị Tadžikistane, o pasisakydamas dẻl individualaus pavojaus pareiškèjui, nurodè, kad tam tikros grupès narių persekiojimo buvimas yra pakankamas, kad būtų nustatytas individualus pavojus ${ }^{16}$. Antra, nors Teismas ir toliau pripažista, kad bendro pobūdžio smurto situacija šalyje paprastai nesukelia 3 straipsnio pažeidimų išsiuntimo kontekste ${ }^{17}$, vis dèlto neatmeta galimybès, kad tokia situacija gali pasiekti toki intensyvumo lygị, kad 3 straipsnis išsiuntimo atveju vis dèlto būtų pažeistas ${ }^{18}$. NA prieš Jungtinę Karalystę byloje Teismas pirmą kartą pripažino galimybę, kad bendro smurto pavojus pats savaime gali reikšti visų išsiuntimų uždraudimą ${ }^{19}$. Tam tikrais atvejais ne tik smurto intensyvumas, bet ir bendros padeties rimtumas gali lemti bylos baigti prieglobsčio prašytojo naudai. Pavyzdžiui, ịvertinęs bendro pavojaus situaciją $M$. S. S. priěs Graikija ir Belgiją byloje, Teismas pripažino pažeidimu bendrą prieglobsčio prašytojų padètị Graikijoje, o ne vien individualias aplinkybes ${ }^{20}$. Trečia, pastaraisiais metais Teismas pripažino pažeidimus ir tais atvejais, kai buvo nustatyti bendri pavojai, asmeninès aplinkybės arba abiejų samplaika ${ }^{21}$. Byloje Sufi ir Elmi prieš Jungtinę Karalystę Teismas nurodè, kad bendro smurto situacija nèra vienintelis pavojus, kuri gali patirti sugrąžintas asmuo. Tose Somalio vietovèse, kuriose bendro smurto lygis yra žemiausias, žmogaus teisių padètis visgi yra blogiausia. Todèl net jei pareiškèjas ir nepatirs netinkamo elgesio dèl bendro smurto pavojaus, jis vis tiek gali susidurti su realiu netinkamo elgesio pavojumi dẻl žmogaus teisių padėties tam tikrose vietovėse ${ }^{22}$. Toje pačioje byloje dèl kitų Somalio vietovių Teismas pripažino, kad (pvz., Mogadiše) bendro smurto pavojus yra pakankamai intensyvus, kad būtų galima daryti išvadą, jog grąžinamas asmuo susidurs su netinkamo elgesio pavojumi vien dèl buvimo ten ${ }^{23}$. Ketvirta, Teismas visiškai neatmeta individualizacijos reikalavimo. Kai kuriose bylose individualios aplinkybės, Teismo nuomone, patvirtinta bendro smurto pavojų. Viename iš naujausių sprendimų byloje Mo. M. prieš Prancūziją (2013 m. balandžio 18 d.) Teismas pripažino konvencijos 3 straipsnio pažeidimą, nes tiek bendra padètis Čade nebuvo stabili, tiek ir pats pareiškèjas pateikè pakankamai įrodymų, kad dèl savo asmeninès situacijos jis patirs netinkamą elgesị, jei bus grąžintas ị Čadą ${ }^{24}$. Taip pat ir Iskandarov prieš Rusija byloje

15 Salah Sheek v. Netherlands, 148 pnk.

16 Case of Sidikovy v. Russia, Appl. No. 73455/11, European Court of Human Rights, Judgement, 20 June 2013 (not final), 146, 149 pnk.

17 NA. v. The United Kingdom, Appl. No. 25904/07, European Court of Human Rights, Judgement, 17 July 2008, 114 pnk.

18 Ibid., 115 pnk.

19 Supra note 1, p. 69.

20 M. S. S. v. Belgium and Greece, 357-358, 401 pnk.

21 Sufi abd Elmi v. The United Kingdom, Appl. No. 8319/07; 11449/07, European Court of Human Rights, Judgement, 28-06-2011, 272, 293 pnk.

22 Sufii and Elmi v. The United Kingdom, 272 pnk.

23 Ibid., 293 pnk.

24 Affaire Mo. M. c. France, Requête no 18372/10, Arrêt, 18 avril 2013, 38, 43 pnk. Šioje byloje buvo sprendžiamas prieglobsčio prašytojo, kuriam buvo atsisakyta suteikti prieglobstį, išsiuntimo ị Čadą klausimas, kur jis bijojo policijos persekiojimo dèl bendradarbiavimo su sukilèliais Darfure. 
Teismas, skirtingai nei Vilvarajah byloje, kurioje pareiškejjo išskirtinumo iš kitų nenustatè, konstatavo, kad pareiškèjo byloje buvo specialūs jị iš kitų išskiriantys požymiai (vienas iš Tadžikistano politinès opozicijos lyderių), dèl kurių Rusijos valdžios institucijos turèjo numatyti, kad su juo Tadžikistane gali būti elgiamasi netinkamai. Teismas pripažino 3 straipsnio pažeidimą, nors nebuvo ịmanoma nustatyti, ar pareiškejjas patyre netinkamą elgesį, kai buvo neteisètai grąžintas ị Tadžikistaną ${ }^{25}$. Panašiai išskirtinius pareiškejjo bruožus Teismas identifikavo ir N. prieš Suomiją byloje, nes pareiškèjas buvo prezidentui Mobutu artimos aplinkos narys ${ }^{26}$.

Apsauga nuo išsiuntimo pagal konvencijos 3 straipsnị nepriklauso nuo asmens savybių, pavyzdžiui, ar jis kelia kokị nors pavojų priimančiajai šaliai. Galima teigti, kad Teismo nuomonè apsaugos absoliutumo atžvilgiu yra susiformavusi ir nesikeičia jau daug metų. Byloje Ahmed prieš Austrija (1996 m.) nustatęs, kad, sprendžiant dèl apsaugos pagal šį straipsnị, asmens elgesys, koks jis bebūtų netinkamas ar pavojingas, negali turèti materialinès reikšmès, Teismas nuosekliai atkartojo savo poziciją ir kitose bylose ${ }^{27}$. Pavyzdžiui, byloje Abdolkhani ir Karimnia prieš Turkija Teismas atmetė Turkijos vyriausybės argumentus, kad leidimas PMOI grupuotès nariams, kuriai priklausè ir pareiškejjai, pasilikti Turkijoje sukeltų pavojų nacionaliniam saugumui ir tvarkai. Teismo nuomone, 3 straipsnio apsauga yra absoliuti ir nepriklauso nuo to, koks pavojingas ar nepageidautinas asmens elgesys, juolab kad pareiškejai paliko PMOI ir Jungtinių Tautų vyriausiojo pabėgèlių reikalų komisaro biuras (JTVPK) juos pripažino pabėgèliais ${ }^{28}$. Nors Teismas pripažįsta, kad valstybès susiduria su rimtais sunkumais užtikrindamos savo bendruomenių apsaugą nuo teroristinès prievartos, vis dèlto tuo pagrindu negali būti ginčyjamas absoliutus 3 straipsnio pobūdis ${ }^{29}$. Teismas atmetė kai kurių valstybių (pvz., Jungtinès Karalystės, Italijos) argumentus, kad pagal 3 straipsnị turètų būti daromas skirtumas tarp valstybės konvencijos dalyvės elgesio ir kitos valstybės elgesio, o pastarosios atveju vis dèlto netinkamo elgesio pavojus turètų būti svarstomas bendrų visuomenės interesų kontekste ${ }^{30}$. Prieglobsčio kontekste apsauga pagal konvencijos 3 straipsni yra net platesnè nei $1951 \mathrm{~m}$. konvencijos, kuri yra specialioji prieglobsčio sutartis, 32 straipsnis bei 33 straipsnio 2 dalies apsauga.

Apsaugos nuo išsiuntimo kontekste vis dažniau valstybès siekia taikyti diplomatines garantijas, kurios turètų užtikrinti, kad su išsiunčiamu asmeniu nebus elgiamasi netinkamai jo kilmès valstybèje. Teismas ne kartą nagrinèjo šį klausimą prieglobsčio prašytojų bylose. Kilmės valstybės diplomatinės garantijos yra tik vienas iš klausimų, i kuriuos Teismas atsižvelgs nagrinėdamas bylą. Reikalaujama, kad jos pakankamai garantuotų, kad išsiunčiamas asmuo bus apsaugotas nuo netinkamo elgesio realiai, o ne tik teoriškai. Vis dèlto garantijoms teikiama reikšmé priklauso nuo konkretaus atvejo

25 Iskandarov v. Russia, 131 pnk.

26 N. v. Finland, Appl. No. 38885/02, European Court of Human Rights, Judgement, 26 July 2005.

27 Chahal v. The United Kingdom, Appl. No. 70/1995/576/662, European Court of Human Rights, Judgement, 15 November 1996, 81 pnk., Saadi v. Italy, 138 pnk.

28 Abdolkhani and Karimnia v. Turkey, 91 pnk.

29 Saadi v. Italy, 137 pnk.

$30 \quad$ Ibid., 138 pnk. 
aplinkybių $^{31}$. Svarstydamas garantijas, Teismas vertina jų kokybinę pusę ir patikimumą (atsižvelgiama i priimančiosios šalies praktiką), t. y. bus svarstoma ${ }^{32}$ :

a) ar garantijos yra bendros ir abstrakčios, ar specifinès;

b) kas išdavė garantijas;

c) ar garantijos yra susijusios su elgesiu, kuris priimančiojoje šalyje yra teisètas ar neteisètas;

d) ar galima objektyviai patikrinti garantijų laikymąsi diplomatiniais ar kitais stebėsenos mechanizmais apimant ir netrukdomą komunikaciją su pareiškejjo teisininkais;

e) ar priimančiojoje šalyje veikia veiksminga apsaugos nuo kankinimų sistema ir ar šalis bendradarbiauja su tarptautiniais stebėsenos mechanizmais (tarp jų ir tarptautinėmis žmogaus teisių nevyriausybinėmis organizacijomis); taip pat ar ji siekia tirti kankinimų įtarimus ir nubausti atsakingus asmenis;

f) ar išsiunčiančiosios valstybès teismai nustatė garantijų patikimumą.

Pavyzdžiui, Chahal prieš Jungtine Karalystę byloje Jungtinè Karalystė (toliau JK) siekè išsiųsti ị Indiją sikhų separatistą, kuris prašè prieglobsčio, nacionalinio saugumo pagrindais ir buvo pateiktos Indijos vyriausybès garantijos, tačiau Teismui vis dèlto jų nepakako, kad pripažintų išsiuntimą galimu. Panašiai ir Baysakov ir kiti prieš Ukraina byloje Teismas nepripažino Kazachstano generalinio prokuroro pavaduotojo garantijų, kad Kazachstano opozicijos nariai - pabėgèliai, kuriuos buvo prašoma išduoti iš Ukrainos, nepatirs netinkamo elgesio, kadangi nesant veiksmingos sistemos, kuri apsaugotų asmenis nuo kankinimų šalyje, būtų sudètinga patikrinti, kaip šių garantijų būtų laikomasi ${ }^{33}$. Taip pat ir 2013 m. priimtame bylos Sidikovy prieš Rusiją sprendime Teismas atmetė galimybę taikyti diplomatines garantijas, kai patikimi šaltiniai nurodo praktikos, kuri yra akivaizdžiai prieštaraujanti EŽTK, buvimą ${ }^{34}$. Tačiau, pavyzdžiui, Omar Othman prieš JK byloje, kurioje Jungtinė Karalystė gavo Jordanijos vyriausybės diplomatines garantijas, Teismo nuomone, jų pakako, kad užtikrintų, jog su pareiškèju nebus netinkamai elgiamasi ${ }^{35}$. Teismas atsižvelgè į tai, kad garantijos buvo labai konkrečios ir visa apimančios, taip pat ị istoriškai itin glaudžius dvišalius santykius tarp Jordanijos ir Jungtinės Karalystės, tai, kad garantijos buvo patvirtintos aukščiausiu lygiu ir kitas aplinkybes ${ }^{36}$.

Kolektyvinio išsiuntimo atvejai Teisme yra reti. Tačiau šiais atvejais Teismas yra pripažinęs pažeidimus pagal konvencijos 4 protokolo 4 straipsnị tuomet, kai asmenys buvo išsiunčiami prièmus bendrą sprendimą dẻl išsiuntimo. Pavyzdžiui, Čonka prieš

\section{Labsi v. Slovakia, 119 pnk.}

Ibid., 120 pnk.

Baysakov and Others v. Ukraine, Appl. No. 54131/08, European Court of Human Rights, Judgement, 18 February 2010, 51 pnk.

Sidikovy v. Russia, 150 pnk.

Othman (Abu Qatada) v. The United Kingdom, Appl. No. 8139/09, European Court of Human Rights, Judgement, 17 January 2012, 205 pnk.

Othman (Abu Qatada) v. The United Kingdom, 194-195 pnk. 
Belgija byloje ${ }^{37}$, nors romų tautybės prieglobsčio prašytojų bylose sprendimai dèl prieglobsčio nesuteikimo buvo priimti po individualaus nagrinejjimo, išsiuntimas buvo grindžiamas bendromis Užsieniečiu įstatymo nuostatomis, nevertinant individualios asmens situacijos, todèl dèl daugybès asmenų buvo priimtas tas pats sprendimas. Tuo tarpu tais atvejais, kai valstybės institucijos, nagrinėdamos prieglobsčio prašymus ir juos atmesdamos, įvertino tiek bendrą situaciją šalyje, tiek ir pareiškejo teiginius, Teismas nepripažino pažeidimo ${ }^{38}$. Hirsi ir kiti prieš Italija byloje pirmą kartą konstatuotas pažeidimas dèl kolektyvinio išsiuntimo ị trečiąą, ne kilmės šalị tuo pažeidžiant 4 protokolo 4 straipsnị.

Išsiuntimo draudimas pagal 3 straipsnị apima ir išsiuntimą ị vadinamąsias trečiąsias valstybes, kuriose nėra užtikrinama apsauga nuo tolesnio išsiuntimo. Šiame kontekste pastaraisiais metais Europos Žmogaus Teisių Teisme susiformavo atskira prieglobsčio bylų kategorija - vadinamosios „Dublino bylos“, kurių skaičius viršijo 1000 bylų ${ }^{39}$. Europos Sajungoje (toliau - ES, Sajunga) sukurtos Dublino sistemos tikslas yra užtikrinti, kad Sajungoje pateiktas prieglobsčio prašymas būtų išnagrinètas bent vienoje valstybejje narejje, o prieglobsčio prašytojai negalètų rinktis, kurioje valstybėje narèje jiems geriau prašyti prieglobsčio. Sistema grindžiama pripažinimu (prielaida), kad ES valstybèse narèse veikia tinkami žmogaus teisių apsaugos standartai (,tarpvalstybinio pasitikëjimo principas"). Pirmą kartą Dublino sistema Teisme buvo kvestionuota dar $2000 \mathrm{~m}$. byloje T. I. prieš $J K$, tačiau tuo metu Teismas buvo tos nuomonès, kad Vokietijoje, kur pareiškejjas turejjo būti išsiųstas, apsauga buvo pakankama, todèl nebuvo realaus pavojaus, kad pareiškèjas bus toliau išsiųstas ị kilmès valstybę - Šri Lanką. Tačiau tuo pat metu Teismas sprendime dèl nepriimtinumo pripažino, kad šios sistemos taikymas neatleidžia valstybių nuo atsakomybès, kuri galètų kilti tuo atveju, jei valstybè, ị kurią asmuo išsiunčiamas, neapsaugotų jo nuo tolesnio grąžinimo ị kilmès šalị, kur gresia pavojus ${ }^{40}$. Vèliau šio principo Teismas išsiuntimų i trečiąsias šalis atveju nuosekliai laikèsi ir kitose bylose ${ }^{41}$. „Dublino bylos“ Teismo sprendimuose vèl atsirado 2008 metais, kai Teismas prièmé labai panašų sprendimą dèl priimtinumo kaip ir T. I. byloje. Byloje K. R. S. prieš $J K$ Teismas nagrinèjo išsiuntimą iš Jungtinės Karalystės ị Graikiją. Teismas vadovavosi prielaida, kad Graikija laikysis savo ịsipareigojimų dèl asmenų, grąžinamų iš kitų ES valstybių narių, nes buvo žinoma, kad ji negrąžina prieglobsčio prašytojų i Iraną. Todèl peticija buvo pripažinta nepriimtina. Vis dèlto visiškai priešingos nuomonès Teismas buvo vienoje svarbiausių pastarojo meto bylų dèl Dublino sistemos - byloje $M$. S. S. prieš Graikija ir Belgija (2011 m.). Šioje byloje Teismas pripažino, jog Belgija pažeidė konvencijos 3 straipsnị išsiųsdama pareiškejją i Graikiją, kurioje veikiančios prieglobsčio procedūros neužtikrino apsaugos nuo išsiuntimo ị kilmès valstybę pavojaus. Šis

37 Čonka v. Belgium, Appl. No. 51564/99, European Court of Human Rights, Judgement, 5 February 2002.

38 Sultani v. France, Appl. No. 45223/05, European Court of Human Rights, Judgement, 20 September 2007, 83-84 pnk.

39 Factsheet „Dublin cases“, European Court of Human Rights, Press Unit, August 2010.

40 T. I. v. The United Kingdom, Appl. No. 43844/98, European Court of Human Rights, Decision, 7 March 2000.

41 Salah Sheekh v. The Netherlands, 141 pnk., Abdolkhani and Karimnia v. Turkey, 88 pnk. 
sprendimas yra priimtas kaip pilotinis Teismo sprendimas ${ }^{42}$, todèl juo visos valstybès konvencijos dalyvės turètų vadovautis kaip gairèmis. Remiantis šiuo sprendimu, valstybès institucijos turi susilaikyti nuo pareiškèjo išsiuntimo pagal Dublino reglamentą ir nuo paties Reglamento taikymo, jei nustato, kad priimanti šalis nevykdo savo įsipareigojimų pagal konvenciją, todèl adekvačios apsaugos prielaida ${ }^{43}$ tokiu atveju neturètų būti taikoma ${ }^{44}$. Išsiuntimo iš vienos ES valstybès narès ị kitą atveju priimant sprendimą, ar asmuo gali būti išsiunčiamas, turi būti atsižvelgiama ị tai, ar asmuo gali pasirūpinti esminiais poreikiais (maistas, pastogè, higiena), asmens pažeidžiamumą, situacijos pagerejjimo tikimybę artimiausiu metu ${ }^{45}$.

Vèlesnèse bylose Teismas nenustatė pakankamai ,realaus ir neišvengiamo pavojaus“, kad pareiškèją išsiuntus ị kitą ES valstybę narę jis bus toliau išsiųstas ị kilmès valstybę arba susidurs su netinkamo elgesio pavojumi, patenkančiu ì 3 straipsnio reglamentavimo sritị. Pavyzdžiui, sisteminès klaidos nebuvo nustatytos dèl bendros prieglobsčio prašytojų padèties Italijoje ${ }^{46}$, taip pat ir naujausių teisès aktų pakeitimai Vengrijoje, kuriais pagerinama prieglobsčio prašytojų padètis, ịtikino Teismą, kad pareiškejjo išsiuntimas pagal Dublino reglamentą nepažeis konvencijos 3 straipsnio ${ }^{47}$. Vis dèlto neaišku, kaip būtų pasibaigusi kita panaši byla - D. H. prieš Suomija $a^{48}$ dèl nepilnamečio prieglobsčio prašytojo išsiuntimo ị Italiją pagal Dublino reglamentą dèl Italijoje susidariusios prieglobsčio prašytojų situacijos, jei Suomija galiausiai nebūtų išdavusi leidimo gyventi šalyje ir byla nebūtų šiuo pagrindu išbraukta iš Teismo bylų sąrašo.

Nagrinejjamos apsaugos nuo išsiuntimo kontekste aktualus yra asmeniui suteikiamo statuso klausimas. Nors EŽTK tiesiogiai nereikalauja valstybių suteikti asmeniui tam tikrą statusą ar išduoti tam tikrą dokumentą ${ }^{49}$, Teismo jurisprudencija šiuo požiūriu kinta. 1996 m. pakako, kad valstybè susilaiko nuo išsiuntimo, o priimančiojoje valsty-

42 Pilotinis sprendimas yra toks EŽTT sprendimas, kuriuo sprendžiamas ne tik konkretus EŽTK pažeidimo klausimas, tačiau ir nustatomos sisteminès problemos valstybėje narèje bei nurodoma, kaip jas spręsti. Factsheet „Pilot Judgements“, European Court of Human Rights, Press Unit, July 2013.

43 Adekvati apsauga (angl. equivalent protection) - EŽTT Bosphorus byloje (Appl. No. 45036/98, 2005-0603) išvystytas principas, kuris reiškia, kad EŽTT pripažista, jog jei tarptautinė organizacija (šiuo atveju Europos Sajunga) gerbia žmogaus teises tokiu būdu, kuris yra adekvatus EŽTK, Teismas daro prielaidą, kad valstybè laikosi ịsipareigojimų pagal konvenciją tuomet, kai ji neturi diskrecijos laisvès veiksmuose, kurie išplaukia iš jos įsipareigojimų tarptautinei organizacijai. Plačiau apie adekvačios apsaugos principą žr. Jočienè, D. Pagrindinių teisių apsauga pagal Europos žmogaus teisių konvenciją ir Europos Sajungos teisę. Jurisprudencija. 2010, 3 (121): 97-113.

44 M. S. S. v. Greece \& Belgium, 340 pnk.

45 Supra note 9, p. 7.

46 Samsam Mohammed Hussein and Others v. the Netherlands and Italy, Appl. No. 27725/10, European Court of Human Rights, Decision, 2 April 2013 (šioje byloje buvo svarstomas Somalio prieglobsčio prašytojos ir jos dviejų nepilnamečių vaikų išsiuntimo iš Nyderlandų i Italiją pagal Dublino reglamentą klausimas).

47 Mohammed v. Austria, Appl. No. 2283/12, European Court of Human Rights, Judgement, 6 June 2013 (šioje byloje Sudano pilietis skundèsi dèl išsiuntimo iš Austrijos i Vengriją pagal Dublino reglamentą, teigdamas, kad dèl šio išsiuntimo jis pateks ị sąlygas, kurios prilygsta nežmoniškam elgesiui, ir kad jo pakartotinio prieglobsčio prašymo pateikimas Austrijoje nesustabdo sprendimo dèl išsiuntimo vykdymo).

48 D. H. v. Finland, Appl. No. 30815/09, European Court of Human Rights, Decision, 28 June 2011.

49 Supra note 1, p. 42, 49. 
bejje asmeniui suteikiamų teisių apimtis nebuvo svarbi (Ahmed priě̌ Austrija). Tačiau 2011 m. Teismas jau nagrinėjo prièmimo sąlygas priimančiojoje valstybẻje bei elgesị su prieglobsčio prašytojais toje šalyje, t. y. nebepasitenkino vien tuo, kad valstybè netaiko išsiuntimo pareiškejjui (M. S. S.). Yra nuomonių, kad Teismas „nukrypo“ nuo ankstesnès jurisprudencijos, pavyzdžiui, $K . R$. S. prieš $J K$ bylos, kai dèl labai panašių aplinkybių kaip ir M. S. S. byloje pažeidimas nebuvo pripažintas ${ }^{50}$. Vis dèlto galima teigti, kad $2008 \mathrm{~m}$. Teismas dar neturèjo tiek informacijos apie prieglobsčio prašytojų padėties Graikijoje problemas ir nenagrinejo priemimo sąlygų, o ịvertino tik tai, kad tuo metu nebuvo pavojaus, jog asmuo iš Graikijos bus išsiųstas ị Iraną, kur jam grésẻ netinkamo elgesio pavojus. Manoma, kad M. S. S. bylos sprendimas gali būti pirmas žingsnis ị teisių, kurių konvencija negina (socialinès, ekonominès ir kultūrinès teisès), teisinę gynybą ${ }^{51}$, nes Teismas šių teisių neužtikrinimą kraštutiniu atveju gali vertinti kaip netinkamą elgesị priimančiojoje valstybèje.

Apibendrinant galima teigti, kad apsauga nuo išsiuntimo pagal konvencijos 3 straipsnị yra aiškiai susiformavusi gausios Teismo jurisprudencijos pagrindu, todèl yra labiausiai prieglobsčio prašytojų naudojama pagal konvenciją. Viena pagrindinių kliūčių prieglobsčio prašytojams ginti savo teises pagal šị straipsnị - pavojaus individualizacijos reikalavimas, artimiausiu metu gali apskritai išnykti, nes Teismas palaipsniui pripažįsta ir pavojus, kylančius dèl priklausymo tam tikrai grupei bei intensyvios smurto ar rimtos žmogaus teisių padèties situacijos. Apsaugos pagal šị straipsnị veiksmingumo požiūriu svarbus klausimas dẻl suteikiamo statuso, sustabdžius išsiuntimą, vis dar nėra išspręstas, nors atrodo, kad Teismo požiūris ị elgesị su asmeniu po išsiuntimo sustabdymo kinta pripažįstant, kad turi būti užtikrinamas bent pagrindinių poreikių tenkinimas. Viena reikšmingiausių apsaugos nuo išsiuntimo pasekmių Teismo jurisprudencijos pagrindu yra pareiga netaikyti ES Dublino reglamento ES valstybių narių tarpusavio išsiuntimuose, jei ES valstybèje nèra laikomasi konvencijoje pripažintų teisių. Valstybių argumentus ir bandymus ginčyti apsaugos absoliutumą keičia vis dažnesnis kilmės valstybės diplomatinių garantijų taikymas, tačiau Teismo pozicija dèl šių garantijų yra itin griežta ir dažniausiai valstybès neįvykdo šioms garantijoms keliamų reikalavimų.

\subsection{Apsauga nuo kankinimų ir nežmoniško elgesio kilmès ir tranzito šalyse}

Šiame poskyryje analizuojami probleminiai asmens situacijos kilmės šalyje ir tranzito šalyje vertinimo Teisme aspektai: žmogaus teisių apsaugos pakankamumo lygis ir humanitarinių situacijų vertinimas, netinkamo elgesio subjektai bei vidaus apsauga. Teismas 3 straipsnio kontekste gresiančio išsiuntimo atvejais vertino labai skirtingas situacijas, kuriose pareiškèjai buvo kilmès ar tranzito šalyse. Konstatuoti netinkamo elgesio draudimo pažeidimai dẻl tokių veikų, kaip: asmeniui gresiančio užmėtymo

50 K. R. S. v. United Kingdom, Application no. 32733/08, European Court of Human Rights, Judgement, 2 December 2008.

51 International Commission of Jurists, Workshop on Migration and Human Rights in Europe, Nonrefoulement in Europe after M. S. S. v. Belgium and Greece, Summary and Conclusions, July 2011, p. 7. 
akmenimis už santuokinę neištikimybę pavojus ${ }^{52}$, politinio oponento šeimai gresiantis persekiojimas Baltarusijoje ${ }^{53}$, sąlygas perkeltujų asmenų stovyklose Somalyje ir kaimyninèse valstybèse ${ }^{54}$. Pripažintas pažeidimas ir dèl teisès ị teisingą teismą neužtikrinimo, nors Teismas prieglobsčio teisių nepripažịsta pilietinėmis teisèmis, todèl laikosi nuomonès, kad konvencijos 6 straipsnis nèra taikomas prieglobsčio prašytojams. Vis dèlto $2012 \mathrm{~m}$. pirmą kartą po dvidešimt dvejų metų nuo Soering sprendimo Teismas byloje Ohman prieš $J K$ pripažino, kad išsiuntimu bus pažeistas 6 straipsnis, nes asmens teismas kilmès valstybejje naudoja kankinimus įrodymams išgauti ${ }^{55}$. Šioje byloje, skirtingai nei Mamatkulov ir Askarov byloje ${ }^{56}$, pareiškejjas įvykde įrodinėjimo naštos reikalavimus, ịrodydamas šiurkštų teisingumo pažeidimo pavojų tuo atveju, jei jis bus išsiųstas ị Jordaniją ${ }^{57}$. Nesenoje byloje $S$. F. ir kiti prieš Švedija (2012 m.) Teismas pripažino 3 straipsnio pažeidimą dèl šeimai iš Irano gresiančio netinkamo elgesio dèl jų politinès veiklos net ne Irane, bet Švedijoje, kur jie prašè prieglobsčio (sur place pagrindu kilusi grèsmė $)^{58}$. Viename naujausių sprendimų I. K. priě̌ Austrija $(2013 \mathrm{~m}$. kovo 28 d. sprendimas, dar negalutinis) Teismas pripažino realaus netinkamo elgesio pavojaus buvimą vien dèl pareiškèjo iš Čečènijos tèvo, kuris priklausẻ sukilèliams, pareigų Čečènijoje ir nužudymo ${ }^{59}$. Galima pastebèti, kad Teismo praktika tikètina gali kisti dèl humanitarinių sąlygų kilmès valstybejje vertinimo. Iki šiol Teismas praktiškai vienkartiniais atvejais pripažindavo 3 straipsnio pažeidimą dẻl kilmès valstybejje susidariusios humanitarinès situacijos ${ }^{60}$, daug dažniau šios situacijos buvo vertinamos kaip nepatenkančios ị 3 straipsnio apimtį ${ }^{61}$. Vis delto $2011 \mathrm{~m}$. Teismas būtent humanitarinių aplinkybių, t. y. minimalių gyvenimo sąlygų neužtikrinimo, situaciją kilmės valstybėje pripažino pažeidusia konvencijos 3 straipsnį $^{62}$. Taip pat Teismas yra nagrinèjęs bylas ir dèl sąlygų tranzito šalyse. Pavyzdžiui, $M . S$. S. byloje pareiškèjo sulaikymo ir gyvenimo sąlygos Graikijoje (skurdas, neužtikrintumas, padèties pagerẻjimo

52 Jabari v. Turkey.

53 Y. P. et L. P. v. France, Requête no. 32476/06, European Court of Human Rights, 2 September 2010, 71 74 pnk. (pažeidimas konstatuotas nepaisant to, kad praèjo nemažai laiko, kadangi situacija Baltarusijoje išlieka nestabili, ypač dèl nuolatinio susidorojimo su režimo oponentais).

54 Sufi and Elmi v. The United Kingdom, 296 pnk.

55 Othman (Abu Qatada) v. The United Kingdom, 260, 285 pnk.

56 Mamatkulov and Askarovv. Turkey, Appl. No. 46827/99 and 46951/99, European Court of Human Rights, Judgement, 4 February 2005.

57 Othman (Abu Qatada) v. The United Kingdom, 285 pnk.

58 S. F. and Others v. Sweden, Appl. No. 52077/10, European Court of Human Rights, Judgement, 15 May 2012.

59 I. K. v. Austria, Appl. No. 2964/12, European Court of Human Rights, Judgement, 28 March 2013, 77-83 pnk.

60 D. v. United Kingdom, Appl. No. 146/1996/767/964, European Court of Human Rights, Judgement, 2 May 1997, Aswat v. the United Kingdom, Appl. No. 17299/12, European Court of Human Rights, Judgement, 16 April 2013, 57 pnk.

61 Pvz., Aoulmi v. France, Appl. No. 50278/99, European Court of Human Rights, Judgement, 17 January 2006; N. v. The United Kingdom, Appl. No. 26565/05, European Court of Human Rights, Judgement, 27 May 2008, I. K. v. Austria, 85 pnk. ir kt.

62 Sufi and Elmi v. The United Kingdom, 296 pnk. 
perspektyvų nebuvimas) buvo pripažintas nežmonišku elgesiu, kuris pažeidžia konvencijos 3 straipsni ${ }^{63}$. Teismas šioje byloje pabrèžė anksčiau nustatytus principus, kad 3 straipsnis negali būti aiškinamas tokiu būdu, kad valstybès narès privalo kiekvienam jų jurisdikcijoje esančiam asmeniui užtikrinti teisę ị namus arba bendrą ịsipareigojimą teikti pabėgèliams finansinę paramą, kad jie galètų užsitikrinti tam tikrą pragyvenimo $\operatorname{lygit}_{i}^{64}$. Tačiau, skirtingai nei ankstesnèse bylose, pareiga suteikti apgyvendinimą ir tam tikras materialines sąlygas skurstantiems prieglobsčio prašytojams, Teismo nuomone, jau tapo pozityviaja teise ir Graikijos institucijos privalo laikytis savo teisès aktų, kurie perkelia Europos bendrijos teisès nuostatas pagal Direktyvą 2003/965. Teismas atsižvelgè i ypatingą padètị kaip prieglobsčio prašytojo, kuriam, kaip itin neprivilegijuotos ir pažeidžiamos visuomenės grupés nariui, reikia specialios apsaugos, todèl 3 straipsnio kontekste turi būti svarstoma kraštutinio materialinio skurdo situacija ${ }^{66}$. Pasakytina, kad ankstesnèse bylose Teismas nebuvo visiškai atmetęs galimybės, kad, gali kilti valstybès atsakomybė tais atvejais, kai pareiškèjas, kuris yra visiškai priklausomas nuo valstybès paramos, susiduria su oficialiu ignoravimu dèl itin didelio nepritekliaus arba situacijos, kuri nesuderinama su asmens orumu“67. Todèl, atsižvelgiant ị tai, kad pareiškèjas buvo itin sunkioje padètyje (daug mėnesių gyveno kraštutinio skurdo sąlygomis ir negalèjo pasirūpinti esminiais poreikiais: maistu, higiena ir gyvenamaja vieta) ir atsižvelgiant i Graikijos įsipareigojimus, kylančius iš ES prièmimo sąlygų direktyvos, Teismo nuomone, Graikija yra atsakinga už neveikimą, nes neatsižvelgè i pažeidžiamą prieglobsčio prašytojo padètí, o pareiškèjas būtent dèl valdžios institucijų kaltès susidūrè su situacija, kuri nesuderinama su konvencijos 3 straipsniu ${ }^{68}$.

Prieglobsčio kontekste svarbios Teismo nagrinètos bylos, kai buvo sprendžiamas klausimas dèl subjekto, kurio veiksmai vertinami kaip netinkamas elgesys 3 straipsnio prasme. Teismo praktikoje tokiais subjektais pripažinti oficialūs asmenys, viršijantys savo ịgaliojimus (Chahal prieš $J K$ ), faktinè valdžia arba sukilèliai (Ahmed prieš Austrija byloje - Somalio ginkluota milicija), privačios grupuotès (H. L. R. priě́ Prancūzija kerštaujantys narkotikų prekeiviai) ir net privatūs individai (N. prieš Švedija - smurtaujantis vyras $)^{69}$. Ši teismo pozicija grindžiama tuo, kad 3 straipsnis garantuoja absoliučią teisę, todèl pareiga susilaikyti nuo pareiškèjo išsiuntimo nepriklauso nuo to, ar netinkamas elgesys gresia dèl veiksnių, kurie apima kilmès valstybès institucijų tiesioginę

63 M. S. S. v. Belgium and Greece, 263 pnk.

64 Ibid., 249 pnk.

65 Tarybos direktyva 2003/9/EB, nustatanti minimalias normas dẻl prieglobsčio prašytojų prièmimo. [2003] OJ L31/18.

66 Šioje byloje pareiškèjas teigè, kad dèl valstybès institucijų sąmoningų veiksmų ar neveikimo jam nebuvo įmanoma naudotis šiomis teisèmis ir užtikrinti savo esminių poreikių, M. S. S. v. Belgium and Greece, 249, 251-252 pnk.

67 M. S. S. v. Belgium and Greece, 253 pnk.

68 Ibid., 254, 263-264 pnk.

69 Šioje byloje Teismas pripažino 3 straipsnio pažeidimą dèl Afganistano moters, kuri, išsiskyrusi su savo vyru dèl smurto namuose pavojaus, susidūrè su išsiuntimo ị Afganistaną, kuriame smurtas šeimoje laikomas teisètu ir todèl valdžios institucijos nepersekioja smurtautojų, grèsme, N. v. Sweden, Appl. No. 23505/09, European Court of Human Rights, Judgement, 20 July 2010. 
ar netiesioginę atsakomybę. Todèl, Teismo nuomone, konvencijos 3 straipsnis taip pat taikomas situacijose, kai pavojus kyla iš asmenų ar jų grupių, kurie nėra valstybès pareigūnai. Šiuo atveju svarbu tai, ar pareiškèjas gali gauti apsaugą ir siekti teisių gynybos dèl prieš jị vykdomų veiksmų ${ }^{70}$. Tais atvejais, kai Teismas pripažįsta ne oficialių, o privačių subjektų veiksmus kaip 3 straipsnio pažeidimą, reikalaujama įrodyti, kad pavojus yra realus ir kad valdžios institucijos nėra pajėgios panaikinti tokí pavojų suteikiant tinkamą apsaugą.

Kitas labai svarbus prieglobsčio bylų aspektas, kurị Teismas nagrinejjo keliose prieglobsčio prašytojų bylose, yra vidinès apsaugos galimybé ${ }^{71}$. Vienoje žinomiausių bylų, Salah Sheek prieš Nyderlandus, Teismas apibrėžè vidaus apsaugos sąlygas, kurioms esant galima atsisakyti suteikti apsaugą asmeniui užsienyje: išsiunčiamas asmuo turi turèti galimybę nuvykti ị saugią vietovę, būti ten priimtas ir įsikurti ${ }^{72} .2011 \mathrm{~m}$. byloje Sufi ir Elmi prieš JK Teismas pabrèžè, kad, nors 3 straipsnis nedraudžia valstybèms taikyti vidinio persikèlimo alternatyvos nuostatą, šis taikymas nepanaikina valstybès pareigos užtikrinti, kad išsiuntimo atveju asmuo nepatirtų netinkamo elgesio ${ }^{73}$. Nors Teismas pripažino, kad pareiškèjai galètų grižti ị Somalị, vis dèlto dèl humanitarinès krizès ir susidariusios ịtampos sugrịžę asmenys negaus prieglobsčio ar paramos tose vietose, kur neturi artimų šeiminių ryšių, todèl labai tikètina, kad turètų gyventi perkeltụjų asmenų arba pabėgèlių stovykloje, kurioje patirtų realų netinkamo elgesio pavojų dèl sudètingų humanitarinių sąlygų ${ }^{74}$.

Teismo jurisprudencija dèl situacijos kilmès valstybejje vertinimo yra labai kazuistinè, tačiau galima teigti, kad šalia pagrindinių pilietinių ir politinių teisių pažeidimų kilmès ir tranzito valstybèse Teismo naujausioje jurisprudencijoje prieglobsčio prašytojai randa teigiamą atsaką ir dèl socialinių-ekonominių teisių pažeidimų bei sudètingų humanitarinių situacijų. Nors konvencija negina šių teisių, nauja Teismo pozicija šiuo klausimu teikia vilčių dèl netiesioginio šių teisių gynimo per netinkamo elgesio draudimą. Teismo pozicija dẻl netinkamo elgesio subjektų yra susiformavusi ir apsauga pagal 3 straipsnį nepriklauso nuo netinkamo elgesio šaltinio. Panašiai kaip ir Teismo praktika dèl vidaus apsaugos, kuri yra aiškiai apibrèžta ir Teismas nuosekliai taiko Salah Sheek byloje nustatytus vidaus apsaugos kriterijus tuomet, kai valstybės kelia šios apsaugos taikymo būtinumo klausimą.

\subsection{Apsauga nuo sulaikymo}

Prieglobsčio kontekste EŽTT nagrinèjo prieglobsčio prašytojų sulaikymo sąvokos, teisètumo, trukmès, sulaikymo sąlygų klausimus. Konvencijos 5 straipsnis numato as-

70 Abdolkhani and Karimnia v. Turkey, 74 pnk., Salah Sheek v. Netherlands, 147 pnk.

71 Salah Sheekh v. the Netherlands, 141 pnk., Chahal v. the United Kingdom, 98 pnk., Hilal v. The United Kingdom, Appl. No. 45276/99, European Court of Human Rights, Judgement, 6 June 2001, 67-68 pnk.

72 Salah Sheek v. Netherlands, 141 pnk.

73 T. I. v. the United Kingdom, Sufi\&Elmi v. The United Kingdom, 266 pnk.

74 Sufi and Elmi v. The United Kingdom, 267, 292, 296 pnk. 
mens fizinę laisvę, o jo tikslas yra apsaugoti asmenis nuo savavališko laisvės atėmimo ${ }^{75}$. Sulaikymo sąvokos prasme, siekiant nustatyti, ar kam nors buvo atimta laisvė, pirmiausia reikia nagrinèti konkrečią asmens situaciją ir visą kompleksą ịvairių kriterijų, tokių kaip ginčijamos priemonès tipas, trukmé, poveikis ir igyvendinimo büdas ${ }^{76}$. Byloje Abdolkhani ir Karimnia prieš Turkiją, kurioje vyriausybe ginčijo sulaikymo buvimą konvencijos 5 straipsnio prasme, Teismas atkreipè dėmesị, kad pareiškejjai negalëjo laisvai palikti policijos nuovados ir Užsieniečių prièmimo ir apgyvendinimo centro, galèjo susitikti su teisininku, tik jei jis gali pateikti notaro patvirtintą igaliojimą, Jungtiniu Tautų vyriausiojo pabėgèlių reikalų komisaro atstovas susitikti su pareiškejjais galëjo tik gavęs vidaus reikalų ministerijos leidimą. Šiomis aplinkybėmis Teismas neprièmė vyriausybès teiginių, kad sulaikymu gali būti vadinamas tik ikiteisminis sulaikymas baudžiamajame procese. Pareiškèjo apgyvendinimas minètose patalpose prilygo „laisvès

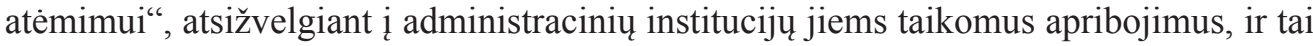
nepriklauso nuo to, kaip jie vadinami pagal nacionalinę teisę ${ }^{77}$. Teismas taip pat atmetè valstybiu argumentus, kad sulaikymas oro uostų tranzito zonose laukiant įleidimo ị valstybès teritoriją ir prieglobsčio prašymo nagrinèjimo procedūra nèra sulaikymas konvencijos prasme, nors asmenys ir yra „laisvi išvykti iš šalies" ${ }^{678}$.

Pagal konvencijos 5 straipsnį sulaikymas leidžiamas tik dẻl tų pagrindų, kurie įeina ị baigtinị leistinų pagrindų sąrašą, ir bus teisetas tik tuomet, jei paskirtas pagal vieną iš $\mathrm{ju}^{79}$. Šie pagrindai turi būti aiškinami siaurinamai ${ }^{80}$. Viena iš išimčių, kai asmens laisvè gali būti ribojama, yra imigracijos kontrolès kontekstas ${ }^{81}$. Situacijas, kai asmuo atvyksta neteisètai ir neturi atitinkamų dokumentų, Teismas vertina kaip patenkančias ị 5 straipsnio 1 dalies f punkto taikymo sriț ${ }^{82}$, todèl kartais ji aktuali ir prieglobsčio prašytojams, kurie ne visuomet turi galimybę atvykti teisètai. Ši nuostata nereikalauja sulaikymo būtinumo (pvz., norint užkirsti kelią nusikaltimo padarymui arba išvykimui), todèl bet kuris sulaikymas bus pateisinamas tik tol, kol išsiuntimo procedūra yra vykdoma ${ }^{83}$. Tačiau jei šios procedūros nèra tinkamai vykdomos, sulaikymas nebebus pateisinamas pagal šią nuostatą ${ }^{84}$. Todèl Teismas nustatė 5 straipsnio 1 dalies pažeidimą prieglobsčio prašytojo iš Turkijos atveju, nes jam, kaip prieglobsčio prašytojui, išsiuntimas, ir atitinkamai ir

75 Amuur v. France, Appl. No. 19776/92, European Court of Human Rights, Judgement, 25 June 1996, 42 pnk., Mubilanzila Mayeka and Kaniki Mitunga v. Belgium, Appl. No. 13178/03, European Court of Human Rights, Judgement, 12 October 2006, 96 pnk.

Abdolkhani and Karimnia v. Turkey, 125 pnk., Amuur v. France, 42 pnk.

77 Ibid., 127 pnk.

78 Amuur v. France, 48 pnk., Idiab v. Belgium, Appl. No. 29787/03, 29810/03, European Court of Human Rights, Judgement, 24-01-2008, 78, 98 pnk.

79 Abdolkhani and Karimnia v. Turkey, 128 pnk.

80 Čonka v. Belgium, 42 pnk., Mubilanzila Mayeka and Kaniki Mitunga v. Belgium, 96 pnk.

81 A and Others v. United Kingdom, Appl. No. 3455/05, European Court of Human Rights, Judgement, 19 February 2009, 162-163 pnk., Saadi v. United Kingdom, Appl. No. 13229/03, European Court of Human Rights, Judgement, 29 January 2008, 43 pnk.

82 Mubilanzila Mayeka and Kaniki Mitunga v. Belgium, 101 pnk.

83 Chahal v. the United Kingdom, 112 pnk.

84 Abdolkhani and Karimnia v. Turkey, 129 pnk. 
sulaikymas išsiuntimo tikslu, negalèjo būti taikytas, o valdžios institucijos neatsižvelgè i jo kaip prieglobsčio prašytojo statusą ${ }^{85}$. Teismo nuomone, prieglobsčio prašytojų, kaip beje, ir kitų asmenų, sulaikymas turi būti ne tik pagrịstas įstatymo lygmens teisès aktų reikalavimais $^{86}$, bet ir teisètas. Tai reiškia, kad turi būti laikomasi įstatymo nustatytos procedūros, sulaikymas turi būti vykdomas atsižvelgiant ị 5 straipsnio tikslą, t. y. apsaugoti asmenị nuo savivalès, ir turi būti pagrịstas nacionalinès teisès nuostatomis. Šie žodžiai reiškia ne šiaip rèmimąsi nacionalinės teisės nuostatomis, bet šių nuostatų kokybę $e^{87}$. Kokybė šiame kontekste reiškia, kad nacionalinè teisè, numatanti laisvès atėmimą, turi būti pakankamai prieinama ir tiksli, kad būtų išvengta visų savavališkumo pavojų ${ }^{88}$.

Teisètumo požiūriu kaip probleminę situaciją Teismas įvertino aiškių teisinių nuostatų, kurios nustato sulaikymo skyrimo ir pratęsimo procedūrą išsiuntimo tikslu bei tokio sulaikymo trukmę, nebuvimą. Nacionalinè sistema nesugebėjo apsaugoti prieglobsčio prašytojų nuo savavališko sulaikymo, pareiškèjų sulaikymas neatitiko tinkamos apsaugos nuo savivalès standartų ir todèl negali būti vertinamas kaip teisètas konvencijos 5 straipsnio prasme ${ }^{89}$. Prieglobsčio prašytojai negali būti apgaulès būdu kviečiami atvykti ì policijos įstaigą tariamai supažindinimo su prieglobsčio sprendimu tikslu, nors tikrasis tikslas yra juos sulaikyti, kad vèliau būtų galima juos išsiųsti ${ }^{90}$.

Sulaikymo sąlygų klausimu gali būti keliamas klausimas ne tik dèl 5 straipsnio, bet ir dèl 3 straipsnio pažeidimo. Galima teigti, kad apskritai migrantų, kurie sulaikomi imigracijos kontrolès tikslais, teisinis statusas yra skirtingas nuo nuteistųų arba kaltinamųjų asmenų, todèl su jais ir turètų būti elgiamasi atsižvelgiant ị šị statusą. Todẻl jie turi būti laikomi tinkamomis sąlygomis, atitinkančiomis jų specifinę situaciją ${ }^{11}$. Teismas yra pripažinęs netinkamu pabėgėlių laikymą 3 mèn. policijos nuovados rūsyje ${ }^{92}$, sulaikymą daugiau kaip 10 dienų oro uosto tranzito zonoje, kur pareiškèjai negalejo pasirūpinti savo esminiais poreikiais ${ }^{93}$. Itin daug bylų buvo dèl prieglobsčio prašytojų sulaikymo sąlygų Graikijos sulaikymo centruose. Pavyzdžiui, žeminančiu arba nežmonišku elgesiu buvo pripažintas: laikymas 2 mèn. kabinoje neleidžiant išeiti ị lauką arba paskambinti, nepakankamas higienos priemonių buvimas ${ }^{94}$; 6 dienų sulaikymas uždaroje patalpoje neleidžiant pasivaikščioti ir laisvai nueiti ị tualetą ${ }^{95} ; 3$ mèn. sulaikymas policijos nuova-

85 Affaire S. D. v. Grèce, Requête no 53541/07, Arrêt, Grand Chamber 11 juin 2009, 67 pnk.

86 Amuur v. France, 50 pnk.

87 Abdolkhani and Karimnia v. Turkey, 130 pnk., taip pat supra note 1, p. 148.

88 Mubilanzila Mayeka and Kaniki Mitunga v. Belgium, 97 pnk.

89 Abdolkhani and Karimnia v. Turkey, 130 pnk., Nasrulloyev v. Russia, Appl. No. 656/06, European Court of Human Rights, Judgement, 11 October 2007, 77 pnk., Chahal v. the United Kingdom, 118 pnk.; Saadi v. the United Kingdom, 74 pnk.

90 Čnka v. Belgium.

91 Ktistakis, Y. Protecting Migrants under the European Convention of Human Rights and the European Social Charter. A Handbook for Legal Practitioners.Council of Europe Publishing, February 2013, p. 33-34.

92 Abdolkhani and Karimnia v. Turkey.

93 Idiab v. Belgium, 106 pnk.

94 S. D. v. Greece, 49-54 pnk.

95 Ibid., 51 pnk. 
doje nesuteikiant tinkamo maisto; ${ }^{96}$ sulaikymas 3 mèn. itin perpildytoje vietoje, kurioje higienos būklè buvo labai prasta, nebuvo laisvalaikio ar maitinimo galimybių, o sanitarinių erdvių būklè buvo tokia, kad jomis praktiškai nebuvo įmanoma naudotis ${ }^{97}$; prieglobsčio prašytojų skyrius buvo retai rakinamas, o sulaikyti asmenys neturèjo priejjimo prie vandens ir turèjo gerti vandenị iš tualetų, patalpos buvo itin perpildytos, o kai kur viena lova tekdavo 14-17 asmenų, nebuvo pakankamai čiužinių, todèl asmenys miegojo ant plikų grindų, nebuvo pakankamos ventiliacijos, o patekimas į tualetus buvo griežtai apribotas, todèl sulaikytieji turèjo tuštintis ì plastikinius butelius ir t. t. ${ }^{98}$ Pažymètina, kad, pavyzdžiui, $M . S$. S. byloje ne tik Graikija buvo pripažinta pažeidusia konvencijos 3 straipsni, nes laikè prieglobsčio prašytoją žeminančiomis sulaikymo sąlygomis, bet ir Belgija, kuri išsiunte prieglobsčio prašytoją žinodama, kad jis bus laikomas tokiomis sąlygomis Graikijoje ${ }^{99}$.

Mubilanzila Mayeka ir Kaniki Mitunga prieš Belgija byloje Teismas nagrinèjo pažeidžiamų asmenų sulaikymo situaciją (šiuo atveju nepilnametės) ir pabrèžè, kad mergaitès laikymas uždarame nelegalių migrantų centre tokiomis pačiomis sąlygomis, kaip ir suaugusių asmenų, nebuvo pritaikytas prie jos itin pažeidžiamos situacijos, todèl Belgijos teisiné sistema nepakankamai apsaugojo jos teisę ị laisvę pažeisdama konvencijos 5 straipsnio 1 dalį ${ }^{100}$. Sulaikymo sąlygos buvo pripažintos netinkamomis ir pažeidusiomis 3 straipsni, taip pat buvo pripažintas 5 straipsnio 1 dalies pažeidimas, nes sulaikymas nebuvo vertinamas kaip teisètas ir kito nelydimo nepilnamečio byloje ${ }^{101}$. Mažamečių vaikų, kurie, nors ir buvo sulaikyti su tėvais, atveju taip pat buvo pripažintas 3 ir 5 straipsnio pažeidimas, kadangi jie buvo sulaikyti jų amžiui nepritaikytomis sąlygomis, o sulaikymas nebuvo pagrịstai būtinas ${ }^{102}$.

Prieglobsčio prašytojų sulaikymo trukmės klausimu vienareikšmio atsakymo nėra, nes tai itin priklauso nuo individualių aplinkybių. Vienu atveju prieglobsčio prašytojo sulaikymas vos kelioms dienoms ${ }^{103}$ pažeide 5 straipsni, tuo tarpu kitu - net ir trejų su puse metų sulaikymo trukmé atsižvelgiant ị asmens pavojingumą, taip pat tai, kad asmens prašymai buvo nuolatos teismų peržiūrimi, buvo pripažinta teisèta ${ }^{104}$. Pavyzdžiui, M. S. S. byloje du prieglobsčio prašytojo sulaikymai keturioms dienoms Teismui neatrodė nereikšmingi, kaip teigė vyriausybė. Teismas atkreipé dėmesį, kad sulaikyti buvo prieglobsčio prašytojai, kurie buvo itin pažeidžiami dèl jau ankstesnių traumuojančių

96 Tabesh v. Grèce, Requête No 8256/07, European Court of Human Rights, 26 November 2009, 38-44 pnk.

97 A. A. v. Greece, 57-65 pnk.

98 M. S. S. v. Greece and Belgium, 222, 230, 234 pnk.

99 Ibid., 367-368 pnk.

100 Mubilanzila Mayeka and Kaniki Mitunga v. Belgium,103-105 pnk.

101 Affaire Rahimi v. Grèce, Requête No 8687/08, Arrêt de 5 avril 2011, 95, 110 pnk.

102 Popov v. France, Requêtes Nos 39472/07 et 39474/07, European Court of Human Rights, 19 January 2012, 97, 120-121 pnk., Affaire Muskhadzhiyeva et Autres v. Belgique, Requête No 41442/07, Arrêt, 19 janvier 2010, 63, 74-75 pnk.

103 M. S. S. Greece and Belgium, 234 pnk.

104 Chahal v. UK, 117 pnk. 
patirčių, todèl net ir trumpas sulaikymas tokiomis sąlygomis, kuriomis jie buvo laikomi, yra nepriimtinas ${ }^{105}$.

Procesinių teisių prasme prieglobsčio prašytojams turi būti suteikta galimybè ginčyti sulaikymo teisètumą teisme, ir tokia sulaikymo peržiūra, kai būtina, turètų lemti asmens paleidimą iš sulaikymo. Praktika, kai pareiškèjai nėra informuojami apie sulaikymo pagrindus, pažeidžia konvencijos 5 straipsnio 2 dalį. Be to, jei jiems atsisakoma suteikti teisinę pagalbą ir jie nèra informuojami apie sulaikymo priežastis, jau vien dẻl šių aplinkybių jų teisė apskųsti sulaikymą lieka be jokio veiksmingo pagrindo. Todẻl, Teismo nuomone, Turkijos teisinè sistema neužtikrino pareiškèjams gynybos priemonès, kuri būtų leidusi jų sulaikymo teisminę peržiūrą teisètumo požiūriu (konvencijos 5 straipsnio 4 dalies pažeidimas) ${ }^{106}$. 5 straipsnio 4 dalies pažeidimą Teismas nustatė ir Graikijos atveju, kadangi jos įstatymai tiesiogiai nenumate galimybės ginčyti sulaikymo teisètumo asmenims, kurie negali būti išsiųsti, kol nagrinèjamas jų prieglobsčio prašymas, ir dèl to jie atsidūrè teisiniame vakuume ${ }^{107}$. Konvencijos 5 straipsnio 4 dalyje numatyta teisinès gynybos galimybè turi būti pakankamai užtikrinta ne tik teoriškai, bet ir praktikoje $\mathrm{e}^{108}$.

Apibendrinant galima teigti, kad apsauga nuo sulaikymo prieglobsčio prašytojams gali būti aktuali neteisèto atvykimo ị šali atveju ir tuomet, kai priimamas neigiamas sprendimas dèl prieglobsčio. Jie naudojasi platesne apsauga nei kiti užsieniečiai pagal 5 straipsnį, nes Teismas pripažista jų, kaip prieglobsčio prašytojų, pažeidžiamumą. Atitinkamai iš valstybių reikalaujama sudaryti tokias sąlygas, kurios atitiktų šių asmenų specifinę padèti sulaikymo sąlygų prasme, bet taip pat informavimo, teisinès pagalbos suteikimo ir galimybių ginčyti sulaikymo sprendimą prasme.

\section{4. Šeimos teisès}

Pirmiausia pasakytina, kad Teismas iki šiol yra labai nuoseklus dèl atvykimo i valstybę šeimos susijungimo tikslu, kadangi daugybèje bylų nuo 1985 m. (pirmą kartą konstatuota byloje Abdulaziz, Cabales ir Balcandali prieš $J K$ ) pripažįsta, kad nèra teisès atvykti ị valstybę šeimos susijungimo tikslu. Tačiau asmens išsiuntimas iš šalies, kurioje gyvena artimi jo šeimos nariai, gali pažeisti konvencijos 8 straipsnyje numatytą valstybės pareigą gerbti šeimos gyvenimą ${ }^{109}$. Iš esmès EŽTK 8 straipsnis yra suformuluotas kaip valstybès kišimosi ị šeimos ar privatų gyvenimą draudimas, t. y. kaip negatyvi pareiga ,valstybės institucijos neturi teisès apriboti naudojimosi šiomis teisèmis, išskyrus įstatymu nustatytus atvejus ir kai tai būtina demokratinèje visuomenèje [...]". Tačiau pastaraisiais metais Teismas vysto pozityviujų pareigų pripažinimą šeimos susijungimo atvejais (Mubilanzila Mayeka ir Kaniki Mitunga prieš Belgija). Šioje byloje, atsižvel-

105 M. S. S. Greece and Belgium, 232 pnk.

106 Abdolkhani and Karimnia v. Turkey, 141-142 pnk.

107 S. D. v. Grèce, 76-77 pnk.

108 Abdolkhani and Karimnia v. Turkey, 139 pnk., Chahal v. UK, 127 pnk.

109 Amrollahi v. Denmark, Appl. No. 56811/00, European Court of Human Rights, Judgement, 11 October 2002, 26 pnk. 
giant ị tai, kad pareiškejja buvo nelydima nepilnametė užsienietė, Belgija turejjo pareigą palengvinti jos susijungimą su motina, kuri buvo pripažinta pabėgėle Kanadoje ${ }^{110}$. Pabėgèlių šeimos apsaugos klausimai gali iškilti tuomet, kai prieglobsčiu besinaudojančio asmens šeimos nariai siekia atvykti i priimančiają valstybę šeimos susijungimo tikslu arba kai siekiama pabėgèlị arba asmenį, kuriam atsisakyta suteikti prieglobstị, išsiųsti iš valstybès, kurioje lieka šeimos nariai. Pabėgèlių bylose, kaip ir kitais atvejais pagal konvencijos 8 straipsni, Teismas atlieka vertinimą 3 etapais:

1. privataus (šeimos) gyvenimo nustatymo (žiūrima, ar yra tikri (angl. genuine) šeimos santykiai, artimi asmeniniai santykiai);

2. valstybès kišimosi ị privatų (šeimos) gyvenimą sąlygos ir pagrindai (ar juos numato teisès aktai, kokios kokybès šie teisès aktai, ar apribojimai būtini demokratinejje visuomenèje ir pan.);

3. apribojimų proporcingumas siekiamiems tikslams.

Nustatydamas, ar egzistuoja šeimos gyvenimas, Teismas tarp kitų aplinkybių vertina, ar asmenys gyvena kartu, ar yra finansinis ar veiksmingas priklausomumas ${ }^{111}$. Šeimos sąvokos prasme viena naujausių Teisme nagrinėtų bylų buvo susijusi su valstybės pozicija dèl pabėgèlių šeimų, kurios buvo sukurtos jau po išvykimo iš kilmès valstybès, susijungimo. Byloje Hode ir Abdi prieš Jungtinę Karalystę ${ }^{112}$ šeimos susijungimo klausimas sprendžiamas jau nebe tradiciškai remiantis vien 8 straipsniu, tačiau ir nediskriminacijos draudimu pagal konvencijos 14 straipsnị. Jungtinè Karalystè atsisakẻ leisti pabėgėlio sutuoktinei atvykti ị šali šeimos susijungimo tikslu motyvuojant, kad pora nebuvo susituokusi tuo metu, kai išvyko iš kilmès valstybės. EŽTT nustatė, kad skirtingas elgesys su pareiškèju lyginant su kitomis imigrantų kategorijomis, kaip kad pabėgèliai, kurie susituokė prieš išvykdami iš savo šalies, studentai ar darbuotojai, nebuvo objektyviai ir pagrịstai pateisinamas. Todėl pripažino konvencijos 14 straipsnio (diskriminacijos draudimas) pažeidimą kartu su 8 straipsnio pažeidimu (privataus ir šeimos gyvenimo gerbimas). Šis sprendimas reiškia, kad pabėgèliai gali susituokti ir po to, kai jiems buvo suteiktas prieglobstis ir gali susijungti su šeima Jungtinèje Karalystèje ${ }^{113}$.

Pabėgèlių teisių gynimo pagal 8 straipsnị požiūriu egzistuoja nemaža valstybès diskrecija (angl. margin of appreciation), todèl ir Teismas atsižvelgia į konkuruojančių individo ir visuomenès bendrų interesų pusiausvyrą. Juolab kad, skirtingai nei konvencijos 3 straipsnis, 8 straipsnis nenumato absoliučios šeimos gyvenimo apsaugos. Teismo nuomone, ,[...] ši byla susijusi ne tik su šeimos gyvenimo klausimais, bet ir imigracijos

110 Mubilanzila Mayeka and Kaniki Mitunga v. Belgium, 85 pnk.

111 Winter, K. Presentation at the EJTN Seminar „Migration and Asylum Law“, Session II: The European Convention on Human Rights Articles 3 and 8 Overview of the ECHR and CJEU jurisprudence, 11-12 September 2012, Bucharest, p. 15 [interaktyvus]. [žiūrèta 2013-07-23]. <http://www.ejtn.net/Documents/ About\%20EJTN/Independent\%20Seminars/Session_II_ECHR_Article_3_and_8_WINTER_Karin MAURER-KOBER_Bettina_Seminar_Migration_and_Asylum_Law_11_12_September_2012.pdf > .

112 Hode and Abdiv. The United Kingdom, Appl. No. 22341/09, European Court of Human Rights, Judgement of 6 November 2012.

113 Pasakytina, kad $2011 \mathrm{~m}$. JK pakeite taisykles, siekiant leisti pabėgèliams pirminio leidimo pasilikti šalyje laikotarpiu susijungti su šeimos nariais, su kuriais santuoka buvo sudaryta po išvykimo iš kilmės valstybès. 
klausimais, todèl valstybių pareiga priimti ị savo teritoriją ịsikūrusių imigrantų giminaičius priklauso nuo susijusių asmenų individualių aplinkybių bei bendrųjų interesų ${ }^{114}$. Kriterijus, kaip nustatyti, kad išsiuntimas yra būtinas ir proporcingas, Teismas apibrèžè byloje Amrollahi prieš Daniją, kurioje buvo sprendžiamas Irano pabėgèlio, turinčio laikiną, o vèliau gavusio ir nuolatinị leidimą gyventi Danijoje, išsiuntimo klausimas dèl jo nuteisimo už narkotikų platinimą, nepaisant to, kad Danijoje gyveno jo sutuoktinè ir vaikai. Šioje byloje Teismas nagrinejjo ${ }^{115}$ : pareiškèjo nusikalstamų veiksmų rimtumą ir pobūdį, gyvenimo šalyje trukmę, laikotarpi nuo nusikaltimo padarymo ir pareiškèjo elgesị šiuo laikotarpiu, susijusių asmenų nacionalinị priklausomumą, šeimos padètị (šeiminių ryšių trukmę ir kitus veiksnius, rodančius šeimos santykių veiksmingumą), ar šeimos nariai žinojo apie nusikaltimo padarymą iki santuokos, ar šeimoje yra vaikų ir koks jų amžius, sunkumai, su kuriais, tikètina, susidurs sutuoktinis, jei pareiškèjas bus grąžintas ị kilmès valstybę. Nors Teismo jurisprudencija yra labai kazuistinè, kai kurie autoriai išskiria tris kategorijas asmenų užsieniečių bylose pagal 8 straipsnị $^{116}$ :

1. antros ir trečios kartos imigrantai;

2. užsieniečiai, turintys leidimą gyventi šalyje;

3. prieglobsčio prašytojai, kuriems atsisakyta suteikti prieglobstị.

Asmenys, kuriems jau suteiktas prieglobstis, būtų priskirti prie antrosios kategorijos, kadangi jie turi stabilų statusą šalyje. Taip pat reikètų išskirti ir ketvirtają grupę prieglobsčio prašytojus, kurie dar tik laukia prieglobsčio sprendimo. Vis dèlto tokių asmenų bylos Strasbūre yra itin retos, kadangi, dažniausiai nustačius pavojų kilmès valstybėje, pareiškejjo išsiuntimas sustabdomas pagal konvencijos 3 straipsnị ir 8 straipsnio pažeidimo klausimas atskirai nėra nagrinejjamas ${ }^{117}$. Lygindama imigrantų ir prieglobsčio prašytojų, kuriems atsisakyta suteikti prieglobstį, bylas, Karin Winter daro išvadą, kad Teismo pozicija yra griežtesnè pastarųų atžvilgiu ${ }^{118}$. Pavyzdžiui, byloje Nnyanzi prieš $J K$ prieglobsčio prašytojos iš Ugandos, kuriai buvo atsisakyta suteikti prieglobstị ir grèsė išsiuntimas, ryšiai su bažnyčia ir santykiai su dabartiniu vaikinu Jungtinėje Karalystejje, Teismo nuomone, nebuvo kliūtimis vykdyti išsiuntimą. Šiuo atveju Teimas konstatavo, kad išsiuntimas nebus neproporcingas, nes pareiškèjos padètis Jungtinèje Karalystejje visuomet buvo nestabili ir ji neturi čia teisinio statuso ${ }^{119}$. Galima sutikti, kad tais atvejais, kai jau atsisakyta suteikti prieglobsčio prašymą, labiau tikètina, kad Teismas nenustatys kliūčių tokị išsiuntimą ịvykdyti, nes jau išnagrinèta, kad asmeniui nèra grèsmès kilmès valstybėje. Tačiau reikètų pasakyti, kad vis dèlto Teismo pozicija prieglobsčio prašytojų, kuriems dar nėra atsisakyta suteikti prieglobstị ir kurie vis dar neturi stabilaus teisinio statuso valstybėje, atveju galètų būti ir kitokia, jei būtų nusta-

114 Gül v. Switzerland, Appl. No. 23218/94, European Commission on Human Rights, Judgement, 10-101994.

115 Amrollahi v. Denmark, 35 pnk.

116 Winter, K., supra note 111.

117 Pvz., I. K. v. Austria (2013 m.), 91 pnk.

118 Winter, K., op. cit., p. 18.

119 Nnyanzi v. United Kingdom, Appl. No. 21878/06, European Court of Human Rights, Judgement, 8 April 2008, 76 pnk. 
tyta, kad jie negali tęsti šeimos gyvenimo kilmès valstybeje, jei ten egzistuoja pavojai. Todėl itin svarbus aspektas prieglobsčio bylose, kuriuo jos skiriasi nuo imigracinių bylų, yra tai, kad Teismas nagrinèja, ar asmuo galètų tęsti šeimos gyvenimą kitoje nei priimančiojoje šalyje, o pabėgèlių atveju tai dažniausiai neịmanoma dėl jų specifinès padèties (grèsmès kilmès valstybejje). Vis dèlto čia situacija gali skirtis priklausomai nuo to, ar asmuo yra pabėgèlio statusu besinaudojantis, ar gavęs tik papildomą apsaugą prieglobsčio valstybejje. Antruoju atveju apsauga pagal 8 straipsnị bus siauresnè. Pavyzdžiui, Gül prieš Šveicarija byloje Teismas nenustate kliūčių, dèl ko šeimos gyvenimas negalètų būti tęsiamas kilmès valstybèje (Turkijoje), kurioje visuomet gyveno pareiškèjo nepilnamečiai sūnūs. Tuo tarpu buvusio pabėgèlio iš Turkijos, kuris gyvena Rumunijoje daugybę metų, yra vedęs ir siejamas su įmonėmis Rumunijoje, atveju Teismas manè, kad išsiuntimas nacionalinio saugumo pagrindais pažeis konvencijos 8 straipsnị ${ }^{120}$. Tiesa, galimybę tęsti šeimos gyvenimą kitoje šalyje Teismas nagrinèjo ir buvusių prieglobsčio prašytojų bylose. Pavyzdžiui, Darren Omoregie ir kiti prieš Norvegija, kurioje buvęs prieglobsčio prašytojas buvo išsiųstas ị Nigeriją nepaisant to, kad jo šeimos nariai liko Norvegijoje, Teismas nenustate šeimos gyvenimo pažeidimo, nes pareiškejjo sutuoktinè galèjo gyventi su juo Nigerijoje. Buvo įvertinta tai, kad ji susidurs su tam tikrais sunkumais ir nepatogumais Nigerijoje, tačiau šie sunkumai nèra neįveikiami $^{121}$. Kita vertus, jei tokie sunkumai yra akivaizdūs ir rimti, nors šeimai ir nebūtų neįmanoma gyventi pareiškejjo kilmès šalyje, Teismas visgi pripažịsta išsiuntimą kaip neproporcingą priemonę. Pavyzdžiui, byloje Amrollahi Teismas įvertino tai, kad pareiškejjo sutuoktinè - Danijos pilietė, niekuomet nebuvo Irane, nežino farsi kalbos, nèra musulmonė ir neturi jokių ryšių su šia šalimi, išskyrus santuoką su Irano piliečiu, pareiškèjo i̊dukra atsisako vykti ị Iraną, todèl buvo tos nuomonès, kad šiuo atveju nebūtų galima tikètis, kad jos galès išvykti kartu su pareiškejju i Iraną ${ }^{122}$, o pareiškèjo išsiuntimas išskirs šeimą tuo pažeisdamas konvencijos 8 straipsnị, kadangi faktiškai jiems nèra įmanoma tęsti šeimos gyvenimo kitoje šalyje ${ }^{123}$. Pažymėtina, kad galimybė tęsti gyvenimą kitoje šalyje Teismo jurisprudencijoje yra svarstoma ne tik dèl kilmės valstybès, tačiau ir dèl trečiujų šalių. Pavyzdžiui, jau minėtoje Amrollahi byloje Teismas atkreipè dėmesị, kad pareiškejjas gyveno Turkijoje ir Graikijoje, tačiau šiose šalyse neturejo teisinio statuso ar ryšių, todėl negalètų gauti teisèto leidimo gyventi kitose šalyse nei pareiškèjo kilmès šalyje Irane ${ }^{124}$. Vis dèlto jei pareiškèjo tinkami ryšiai ir teisinis statusas egzistuotų trečiojoje šalyje, Teismas, matyt, būtų kitos nuomonès dẻl išsiuntimo.

Taigi, prieglobsčio prašytojų bylos pagal 8 straipsnị yra itin retos, nes jie naudojasi 3 straipsnio apsauga, kuri yra platesnè, vis dèlto apsaugos pagal ši straipsnị veiksmingumas priklauso dažniausiai nuo to, ar šeima galès tęsti šeimos gyvenimą kitoje šalyje. Todèl prieglobsčio prašytojų ir pabėgèlių apsauga pagal 8 straipsnị pasižymi specifiš-

120 Geleri v. Romania, Appl. No. 33118/05, European Court of Human Rights, Judgement, 15-02-2011.

121 Omoregie and Others v. Norway, Appl. No. 265/07, European Court of Human Rights, Judgement, 31-072008, 66 pnk.

122 Amrollahi v. Denmark, 41 pnk.

123 Ibid., 43 pnk.

124 Ibid., 42 pnk. 
kumu nuo kitų užsieniečių tiek, kiek šie asmenys negali tęsti šeimos gyvenimo kilmės valstybèje dèl ten jiems gresiančio pavojaus. Priklausomai nuo suteikto statuso pobūdžio (pabėgèlio statusas ar papildoma apsauga) šeimos teisių apsauga gali būti siauresnè ar platesnè. Nors 8 straipsnis negina teisès ị šeimos susijungimą, bent jau nepilnamečių atveju atsiranda pripažinimas, kad valstybė turi pozityvias pareigas palengvinti tokị susijungimą. Taip pat galima teigti, kad pabėgèlių atveju šeimos teisės paga ši straipsnị gali būti ginamos nepriklausomai nuo to, ar šeima buvo sukurta kilmès valstybejje, ar iš jos išvykus.

\subsection{Teisè ị veiksmingą teisinę gynybą}

Veiksminga teisinė gynyba prieglobsčio prašytojams aktuali keliais aspektais: pirma - dèl galimybės pateikti prieglobsčio prašymą ir jo nagrinèjimo, antra - dèl teisès apskųsti priimtą sprendimą nesuteikti prieglobsčio ar konkrečios apsaugos formos. Vis dèlto dažniausiai veiksmingos teisinès gynybos klausimas Europos Žmogaus Teisių Teisme iškyla išsiuntimo procedūrų kontekste, kai prieglobsčio prašytojams atsisakoma suteikti prieglobstị ir planuojama juos išsiųsti iš šalies. Pastarųjų metų tendencija veiksmingos teisinès gynybos klausimai, nagrinejjami prieglobsčio prašytojų, kuriems dar nebuvo atsisakyta suteikti prieglobstį, bet kuriuos planuojama perduoti iš vienos ES valstybės narès ị kitą procedūrų metu (Dublino procedūra, plačiau žr. 1.1 poskyryje). Prieglobsčio prašytojų teisė į veiksmingą teisinę gynybą Teismo buvo nagrinèta konvencijos 13 straipsnio kontekste (dažniausiai kartu su 3 straipsniu), 5 straipsnio 4 dalies kontekste (pastarasis dẻl sulaikymo apskundimo) bei 8 straipsnio kontekste. Teismo jurisprudencija iki šiol patvirtina tai, kad teise ị teisingą teismą ir iš to išplaukiančios garantijos nèra taikomos prieglobsčio prašytojams pagal konvencijos 6 straipsni, kadangi prieglobsčio teisès, bent jau kol kas, nèra priskiriamos prie pilietinių teisių ${ }^{125}$. Vis dèlto konvencijos 13 straipsnis nereikalauja, kad teisinès gynybos priemonè būtų būtent ,teismas“, nurodoma tiesiog nacionaline institucija ${ }^{126}$. Santykio tarp 13 straipsnio ir 5 straipsnio 4 dalies požiūriu reikia pasakyti, kad tais atvejais, kai nagrinejjamas teisinès gynybos klausimas sulaikytų prieglobsčio prašytojų atveju, 5 straipsnio 4 dalis apims skundą pagal 13 straipsni, kuris yra ne toks griežtas lyginant su pastaruoju, kuris vertinamas kaip lex specialis dèl 5 straipsnio pažeidimo skundų ${ }^{127}$.

Konvencijos 13 straipsnis garantuoja nacionalinę teisinę gynybos priemonę, kuri gintų konvencijoje įtvirtintas laisves ir teises bet kuria forma. Nors valstybès turi diskreciją pasirinkti, kokiu būdu jos užtikrina ịsipareigojimų pagal ši straipsnị laikymąsi, reikalaujama, kad pasitelkdamos šią priemonę nacionalinès institucijos galètų išnagrinèti tiek skundo esmę, tiek ir atkurtu pažeistą teisę ${ }^{128}$. Tam tikromis aplinkybėmis priemonių, kurias užtikrina nacionalinè teise, visuma gali patenkinti 13 straipsnio reika-

Supra note 1, p. 95.

Ibid.

127 Chahal v. the United Kingdom, 126 pnk., Mubilanzila Mayeka and Kaniki Mitunga v. Belgium, 110 pnk. 
lavimus ${ }^{129}$. Atsižvelgiant ị tai, kad žala gali būti neatitaisoma, jei išsiuntus asmenì jis patirs netinkama elgeș̨, kuris pažeidžia 3 straipsnị, taip pat svarba, kuria teismas teikia šiam straipsniui, veiksmingos teisinès gynybos nuostata pagal 13 straipsni numato: a) nepriklausoma ir išsamu pareiškimo tyrima siekiant nustatyti, ar yra rimtu priežasčiu manyti, kad su asmeniu bus elgiamasi pažeidžiant 3 straipsnị išsiuntimo atveju; b) skundo pateikimas turi sustabdyti išsiuntimo vykdyma ${ }^{130}$. Tais atvejais, kai Teismas nagrinejja prieglobsčio prašytojų, kuriems gresia išsiuntimas, bylas, jis nenagrinėja jų prieglobsčio prašymo esmès, kad ịsitikintų, kaip valstybès laikosi ịsipareigojimų pagal $1951 \mathrm{~m}$. konvenciją. Jo pagrindinis rūpestis yra patikrinti, ar yra veiksmingos priemonès, kurios apsaugotų asmenį nuo tiesioginio ar netiesioginio grąžinimo ị valstybę, iš kurios jis atvyko ${ }^{131}$. Tačiau Teismo reikalavimas, kad valstybė, siekianti išsiųsti prieglobsčio prašytoją, išnagrinètų prieglobsčio prašymą iš esmès, yra viena iš teisinès gynybos veiksmingumo sąlygu pagal 13 straipsnị. Tais atvejais, kai nacionalinès institucijos neatsako pareiškejjams, Teismo nuomone, tai prilygsta „detalaus tyrimo“ (angl. rigorous scrutiny), kurio reikalauja 13 straipsnis, nebuvimui ${ }^{132}$. Tai, kad veiksmingos teisinès gynybos priemone, Teismo nuomone, turi ne tik sustabdyti sprendimo, kuris skundžiamas, vykdymą, tačiau ir užtikrinti kruopštu prieglobsčio prašytojo prašymo išnagrinėjimą, Teismas patvirtino ir M. S. S. byloje ${ }^{133}$. Manoma, kad būtent šioje byloje buvo išplèstas teisinių gynybos priemonių pagal 13 straipsnị vaidmuo, kadangi šioje byloje Teismas pripažino pažeidimą dèl prieglobsčio prašymų nagrinèjimo procedūros Graikijoje bendrų trūkumų, kurie neužtikrino, kad prieglobsčio prašymas būtų išnagrinètas, ir todèl kilo pavojus, kad pareiškejjas bus grąžintas tiesiogiai ar netiesiogiai ị kilmès valstybę rimtai neįvertinus jo prieglobsčio prašymo esmès ir nesuteikiant jam galimybès pasinaudoti veiksminga teisine gynyba ${ }^{134}$. Šiame kontekste svarbus buvo tiek patekimo i prieglobsčio procedūrą klausimas (nepakankama informacija prieglobsčio prašytojams apie procedūras, nepatikima komunikacijos tarp valstybės institucijų ir prieglobsčio prašytojų sistema, sudètingas patekimas ị policijos nuovadą, vertèjų trūkumas, apmokytų darbuotojų, kurie galètų atlikti individualias apklausas, trūkumas, teisinės pagalbos ir informacijos apie organizacijas, kurios teikia teisinę pagalbą, bei teisininkų trūkumas ir itin ilgi sprendimo prièmimo terminai), tiek ir paties prieglobsčio prašymo nagrinèjimas, abiem atvejais buvo nustatyti trūkumai ${ }^{135}$. Esant tokiems trūkumams procedūra negali būti praktikoje veiksminga ir ši situacija gali būti kliūtimi prieglobsčio prašytojui pasinaudoti veiksminga teisine gynyba ${ }^{136}$. Apskritai informacijos trūkumas buvo

129 Chahal v. the United Kingdom, 145 pnk.

130 Abdolkhani and Karimnia v. Turkey, 108 pnk., Muminov v. Russia, Appl. No. 42502/06, European Court of Human Rights, Judgement, 11-12-2008, 101 pnk., Gebremedhin [Gaberamadhien] v. France, Appl. No. 25389/05, European Court of Human Rights, Judgement, 26-04-2007, 66 pnk.; Jabari v. Turkey, 39, 50 pnk.

131 M. S. S. v. Greece and Belgium, 286 pnk., T. I. v. the United Kingdom.

132 Abdolkhani and Karimnia v. Turkey, 113 pnk.

133 M. S. S. v. Belgium and Greece, 293 pnk.

134 Ibid., 321 pnk.

135 Ibid., 301, 319 pnk.

136 Ibid., 319 pnk. 
įvertintas kaip pagrindinè kliūtis pareiškejjams pasinaudoti prieglobsčio procedūromis, tuo tarpu Graikijos valdžios institucijos nesièmė priemonių užtikrinti komunikaciją su pareiškèju ar priimti kokị nors sprendimą jo byloje, tuo nesuteikiant jam jokios realios ir adekvačios galimybès ginti savo prieglobsčio prašymą ${ }^{137}$. Šioje byloje vyriausybė buvo pateikusi nemažai svarių argumentų dẻl paties pareiškèjo neveiklumo (neatvykimas ị policiją registruotis ir į interviu, bandymas išvykti iš šalies nepasinaudojus Graikijos prieglobsčio procedūra ir pan.). Vis dèlto Teismas atsižvelgè ne ị konkretaus asmens elgesi šiuo atveju, bet į bendrą situaciją, t. y. labai žemą apsaugos suteikimo (prieglobsčio ar papildomos apsaugos) statistiką lyginant su kitomis ES valstybėmis narėmis. Teismo nuomone, šios žinomos problemos tik sustiprino pareiškèjo nepasitikèjimą procedūra ${ }^{138}$.

Svarbus kriterijus, nagrinėjant priemonės pagal 13 straipsni veiksmingumą, yra tai, ar teisinè gynybos priemonè yra veiksminga ne tik teisès aktuose, bet ir praktikoje. Pavyzdžiui, Abdolkhani ir Karimnia byloje, Teismas net nenagrinèjo, ar suteiktos priemonès buvo veiksmingos, nes konstatavo daugybinius pažeidimus: pareiškejjų prašymai dèl laikino prieglobsčio visiškai nebuvo svarstomi, apie to priežastis pareiškejjai išvis nebuvo informuoti, galimybė pasinaudoti teisine pagalba apskritai nebuvo suteikta, visa tai užkirto kelią pareiškẻjams apskritai iškelti aplinkybių dèl 3 straipsnio pažeidimo pagal nacionalinę teisę klausimą laikino prieglobsčio procedūroje ${ }^{139}$. Be to, jie net negalèjo kreiptis ị administracines arba teismines institucijas dẻl sprendimo išsiųsti juos atitinkamai ị Iraką ir Iraną panaikinimo, nes jiems niekuomet nebuvo įteikti šie sprendimai, taip pat ir nepraneštos jų išsiuntimo iš Turkijos priežastys. Todèl jų teiginiai, kad jų išsiuntimas atitinkamai į Iraną ir Iraką sukels pasekmių, priešingų konvencijos 3 straipsniui, atsiradimą, niekuomet nebuvo valdžios institucijų išnagrinèti. Šiomis aplinkybėmis pareiškejjai neturejjo veiksmingos ir prieinamos gynybos priemonès dèl jų skundų pagal 3 straipsnį, o tai pažeidè konvencijos 13 straipsnị ${ }^{140}$. Žinoma, šios bylos faktai liudijo itin prastą prieglobsčio procedūrų Turkijoje padètį, tuo tarpu kitais atvejais Teismui tenka spręsti daug subtilesnius priemonès veiksmingumo niuansus. Kitoje byloje, Labsi prieš Slovakika, pareiškejjas, kuriam buvo atsisakyta suteikti prieglobstį, buvo išsiųstas praèjus vienai dienai nuo Slovakijos aukščiausiojo teismo sprendimo, todèl, Teismo nuomone, pareiškejjas neturejo praktinių galimybių pasinaudoti konstitucine teisinės gynybos priemone iki išsiuntimo ${ }^{141}$. Taigi, atsižvelgiant ị tai, kad priemone turi būti veiksminga ir praktikoje, tarp kitų aspektų gali būti svarstoma, ar prieglobsčio prašytojui buvo suteikta pakankamai laiko pateikti skundą ${ }^{142}$.

Labiausiai teisinès gynybos priemonès veiksmingumas Teismo nagrinètose bylose kvestionuotas dèl vadinamojo suspensyvinio apskundimo poveikio (angl. suspensive effect). Teismo nuomonè šiuo klausimu yra nevienareikšme - tais atvejais, kai pareiškèjas skundžia išsiuntimą iš valstybès konvencijos dalyvès, gynybos priemonè bus veiks-

137 M. S. S. v. Belgium and Greece, 304, 313 pnk.

138 Ibid., 313 pnk.

139 Abdolkhani and Karimnia v. Turkey, 115 pnk.

140 Ibid., 58 pnk.

141 Labsi v. Slovakia, 139 pnk.

142 Supra note 1, p. 96. 
minga tik tuomet, kai ji automatiškai sustabdo išsiuntimo vykdymą ${ }^{143}$. Teismo nuomone, teisinės gynybos priemone turi užkirsti kelią priemonių, kurios pažeidžia konvenciją, vykdymui, todẻl situacijas, kai prieglobsčio prašytojai išsiunčiami iš valstybès iki priimamas sprendimas (dèl išsiuntimo priemonès suderinamumo su konvencija), vertina kaip nesuderinamas su konvencijos 13 straipsniu ${ }^{144}$. Todèl, pavyzdžiui, išsiuntimo bylų teisminė peržiūra Turkijoje nebuvo laikoma veiksminga teisinės gynybos priemone, nes išsiuntimo sprendimas nesustabdo išsiuntimo vykdymo, nebent administracinis teismas specialiai priima toki nurodymą ${ }^{145}$. Teismo nuomone, nepakanka, kad praktikoje teismai taiko sprendimo sustabdymą, kadangi veiksmingos teisinės gynybos principas nèra vien tik ketinimų ar praktinio taikymo dalykas. Tai vienas iš esminių demokratinès visuomenės principų. Pareiškejjui nėra jokių garantijų, kad kiekvienu atveju nacionalinis teismas taikys tokią praktiką, todèl visų šių veiksnių kontekste priemonės ịgyvendinimas nèra užtikrintas, kad būtų įvykdomi 13 straipsnio reikalavimai ${ }^{146}$.

Kad prieglobsčio prašytojams būtų užtikrinta veiksminga teisė skųsti priimtus sprendimus, Teismo nuomone, būtina net jūroje. Bylos Hirsi ir kiti prieš Italija sprendime teismas buvo tos nuomonès, kad laivo karinio personalo sprendimo apskundimas neatitiko suspensyvinio poveikio kriterijaus ir todèl pripažintas 13 straipsnio kartu su 4 protokolo 4 straipsniu pažeidimas. Be to, tai, kad pareiškejjai negalejo pateikti savo prašymų kompetentingai institucijai, kuri išsamiai išnagrinètų jų prašymus dar iki išsiuntimo priemonès vykdymo, buvo įvertintas kaip 13 straipsnio kartu su 3 straipsniu pažeidimas. 2012 m. Teismas svarstė paspartintų (skubių) prieglobsčio procedūrų ir suspensyvinio poveikio bei praktinio priemonių prieinamumo klausimą ir kitoje byloje. Byloje $I$. $M$. prieš Prancūziją Teismas nepripažino 3 straipsnio pažeidimo, tačiau buvo konstatuotas 13 straipsnio pažeidimas, kadangi, nors priemonès buvo teoriškai prieinamos, jų praktinis prieinamumas buvo apribotas tuo, kas pareiškèjo prašymas buvo automatiškai užregistruotas pagal skubių prašymų procedūrą, terminai buvo labai trumpi ir buvo praktinių ir procesinių sunkumų, kadangi pareiškèjas buvo sulaikytas ir pirmą kartą prašè prieglobsčio. Veiksmingos teisinès gynybos klausimą pakartotinio prieglobsčio prašymo pateikimo atveju Teismas nagrinejjo Mohammed prieš Austriją byloje (2013 m. birželio $6 \mathrm{~d}$. sprendimas dèl priimtinumo), kadangi pakartotinio prieglobsčio prašymo pateikimas Austrijoje nesustabdè išsiuntimo vykdymo. Teismo nuomonè pakartotinių prieglobsčio prašymų atveju nesiskiria nuo pirminio prieglobsčio prašymo, nes pareiškèjas nebuvo apsaugotas nuo išsiuntimo, nors jo skundas, kad teisès pagal konvenciją bus pažeistos išsiuntimo atveju, buvo pagrịstas. Šioje byloje nebuvo pripažintas 3 straipsnio pažeidimas dẻl pareiškèjo išsiuntimo ị Vengriją pagal ES Dublino reglamentą, tačiau konstatuotas 13 straipsnio kartu su 3 straipsniu pažeidimas. Kitoje, ankstesnejje byloje ${ }^{147}$, pareiškèjo išsiuntimas buvo sustabdytas tik dèl to, kad Teismas taikè laikinąsias priemones pagal Teismo taisyklių 39 punktą ir buvo atkreiptas dèmesys, kad

\footnotetext{
143 Čonka v. Belgium, 79 pnk.

144 Ibid.

145 Abdolkhani and Karimnia v. Turkey, 116, 59 pnk.

146 Čonka v. Belgium, 83 pnk., Gebremedhin [Gaberamadhien] v. France, 66 pnk.

147 Sultani v. France, 65-66 pnk.
} 
skundas Nacionaliniam prieglobsčio teismui nesustabdẻ sprendimo dẻl išsiuntimo vykdymo skubių procedūrų atveju. Teismas apskritai priskiria tokias teisminio apskundimo priemones prie tų, kurios turi būti išnaudotos prieš keipiantis dèl Taisyklès 39 taikymo (laikinosios priemonès) pagal Teismo reglamentą tais atvejais, kai jos yra prieinamos ir kai jos sustabdo išsiuntimo vykdymą ${ }^{148}$. Pažymètina, kad prašymų dèl Taisyklès 39 taikymo skaičius Teisme sparčiai auga ir laikotarpiu nuo 2006 iki 2010 metų augimas buvo per 4000 procentų (pvz., $2006 \mathrm{~m}$. buvo gauta 112 prašymų, $2010 \mathrm{~m}$. šis skaičius išaugo jau iki 4786 prašymų), o Teismo pirmininkas buvo priverstas kreiptis ị valstybes reikalaudamas neišsiųsti užsieniečių tol, kol nèra išnagrinėjami jų skundai ${ }^{149}$. Tarp kitų valstybių veiksmų, kurie gali lemti priemonès neveiksmingumą, Pagrindinių laisvių agentūra priskiria ir tai, kad valstybès nepraneša pareiškẻjui apie sprendimą arba teisę ji apskųsti, arba neleidžiama sulaikytiems prieglobsčio prašytojams susiekti su išoriniu pasauliu ${ }^{150}$.

Apibendrinant pasakytina, kad apsauga pagal 13 straipsni yra glaudžiai susijusi su prieglobsčio procedūroms keliamais reikalavimais (dèl teisès pateikti prieglobsčio prašymą, apskųsti priimtą prieglobsčio sprendimą ir pan.), todèl ją galima vadinti prieglobsčio prašytojų apsaugos pagal EŽTK procesiniu ramsčiu. Prieglobsčio prašytojų apsauga pagal šị straipsnị taikoma tiek patekimo ị prieglobsčio procedūrą stadijoje, tiek ir prièmus neigiamą sprendimą dẻl prieglobsčio. Teismo jurisprudencija yra nevienareikšmẻ dèl reikalavimo, kad prieglobsčio prašymas būtų išnagrinètas iš esmès bei užtikrinta, kad skundo dèl atsisakymo suteikti prieglobstị pateikimas sustabdytų išsiuntimo vykdymą net ir skubių procedūrų ar eksteritorinès jurisdikcijos vykdymo atvejais. Patekimo ị procedūras kontekste itin svarbūs valstybėms keliami reikalavimai dẻl tinkamo informavimo, teisinès pagalbos suteikimo, kurie stiprina prieglobsčio prašytojų teisinę apsaugą prieglobsčio procedūrose.

\section{Prieglobsčio prašytojų teisių apsauga Europos Sąungos Teisingumo Teismo jurisprudencijoje}

Kokią apsaugą siūlo prieglobsčio prašytojams Liuksemburgo sistema lyginant su EŽTT jurisprudencija? Atsakant ị ši klausimą, pirmiausia reikia trumpai aptarti, kokiomis žmogaus teisių apsaugos priemonemis disponuoja ESTT ir kokie yra esminiai šių dviejų teismų vystomų praktikų santykio bruožai. Pradejkime nuo to, kad prieglobsčio prašytojams aktualių teisių, kylančiu iš EŽTK, apsaugos imperatyvai ES teisès sistemoje veikia (galioja) keliais būdais.

148 N. A. v. the United Kingdom, 90 pnk.

149 Governments, applicants and their lawyers urged to co-operate fully with European Court, following "alarming rise" in requests to suspend deportation, Press Release No. 127, Registrar of the Court, European Court of Human Rights, 11.02.11.

Supra note 1, p. 97. 
Pirma, jos veikia kaip bendrieji ES teisès principai. Nuo septinto XX a. dešimtmečio ${ }^{151}$ ESTT išvystè įspūdingą jurisprudenciją, kuria daugybę kartų yra konstatavęs, kad pagrindinès teisès sudaro bendruosius Bendrijos (ES) teisès principus. Su nežymiais pakeitimais Teismo vartojama formulè skamba taip: „Pagrindinès teisès yra sudedamoji bendrųų teisès principų, kurių laikymąsi užtikrina Teisingumo Teismas, dalis. Todėl Teisingumo Teismas vadovaujasi valstybių narių bendromis konstitucinėmis tradicijomis ir tarptautiniais dokumentais žmogaus teisių apsaugos srityje, kuriuos priimant valstybės narès bendradarbiavo ar prie kurių prisijungè. EŽTK šiuo atžvilgiu turi ypatingą reikšmę. "152 Nuo 1999 m. šis požiūris atsispindi ir pirminėje rašytinèje Sajungos teisėje. Sutarties dèl Europos Sajungos veikimo (toliau - SESV) 6 straipsnio 3 dalyje skelbiama, kad ,pagrindinès teisès, kurias garantuoja Europos žmogaus teisių ir pagrindinių laisvių apsaugos konvencija ir kurios kyla iš valstybėms narėms bendrų konstitucinių tradicijų, sudaro Sajungos teisès bendruosius principus“. Kategoriškesnė darosi ir ESTT vartojama kalba, jo teigimu, ES teisès sistema saugo (užtikrina) pagrindines teises, įskaitant teises, išplaukiančias iš EŽTK ${ }^{153}$.

Kaip pabrèžia Battjes, atitikties bendriesiems principams testas taikomas tiek Sąjungos institucijų priimtiems teisès aktams (t. y. antrinei teisei), tiek ES teisę ígyvendinančioms nacionalinėms priemonėms ${ }^{154}$. Ar ị ES teisės taikymo sritị patenkantis nacionalinis aktas nepažeidžia pagrindinių teisių, pirmiausia sprendžia nacionaliniai teismai. Tačiau reaguodamas i prašymą priimti prejudicinị sprendimą ESTT turi pareigą pateikti išsamų išaiškinimą, būtiną nacionaliniam teismui vertinant nacionalinès teisès atitiktị pagrindinėms teisèms ${ }^{155}$. Be to, $N$. S. byloje ESTT priminè valstybėms narèms, kad jos privalo „nesivadovauti tokiu antrinès teisès teksto aiškinimu, kuris pažeistų Sajungos teisès sistemos saugomas pagrindines teises arba kitus bendruosius Sajungos teisès principus" ${ }^{\text {"156. }}$.

ESTT yra pripažinęs ypatingą EŽTK jurisprudencijos vaidmenị nustatant atitinkamos pagrindinès teisès turinị ES teisès sistemoje ${ }^{157}$. Elgafaji byloje ESTT patvirtino šio principo taikymą aiškinant ES prieglobsčio teisyną, pabrèždamas, kad nustatant EŽTK ịtvirtintos teisès apimtị Bendrijos teisès sistemoje turi būti atsižvelgiama ị EŽTT praktiką ${ }^{158}$.

151 Byla C- 29/69, Stauder; byla C-228/69, Handelsgesellschaft.

152 Byla C-540/03, Europos Parlamentas prieš Europos Sajungos Taryba, 35 pnk.

153 Byla C-344/08, Tomasz Rubach, 30 pnk.

154 Hemme, Battjes. European Asylum Law and International Law, Koninklijke Brill NV, Leiden, The Netherlands 2006, p. 83-84.

155 Byla C-94/00, Roquette Frères SA ir Directeur général de la concurrence, de la consommation et de la répression des fraudes, 25 pnk.; Byla C-71/02, Herbert Karner Industrie-Auktionen GmbH v. Troostwijk $\mathrm{GmbH}, 49$ pnk.

156 Sujungtos bylos C-411/10 ir C-493/10, N. S. (C-411/10) v. Secretary of State for the Home Department et M. E. ir kt. (C-493/10) prieš Refugee Applications Commissioner ir Minister for Justice, Equality and Law Reform, 77 pnk.

157 Byla C-94/00, Roquette Frères SA, 29 pnk.

158 Byla C-465/, Meki Elgafaji and Noor Elgafaji prieš Staatssecretaris van Justitie, 28 pnk. 
İsigaliojus Lisabonos sutarčiai, iš EŽTK išplaukiančios ir Sajungos teisės sistemos saugomos pagrindinès teisės virto rašytine pirmine ES teise, nes remiantis SESV 6 straipsnio 1 dalimi ES pagrindinių teisių chartija (toliau - Chartija), kuria inter alia buvo siekiama kodifikuoti bendruosius Bendrijos principus ${ }^{159}$, igijo tokią pat teisinę galią, kaip ir Sutartys. Atsižvelgiant ị Chartijos 52 straipsnio 4 dalị, Chartijoje nurodytų teisių, atitinkančių EŽTK garantuojamas teises, esmè ir taikymo sritis yra adekvati (angl. equivalent) konvencijoje numatytoms teisėms, tačiau Sajungos teisè gali numatyti didesnę apsaugą. Chartijos nuostatoms, kylančioms iš EŽTK ir taikytinoms antrinei ES prieglobsčio teisei bei ją ịgyvendinančioms nacionalinėms priemonèms, pirmiausia priskirtini 4 straipsnis (kankinimų ir nežmoniško ar žeminančio elgesio ar baudimo uždraudimas), 6 straipsnis (teisé ị laisvę ir saugumą), 7 straipsnis (teisé ị privatų ir šeimos gyvenimą), 19 straipsnis (apsauga perkèlimo, išsiuntimo ir išdavimo atveju) ir 47 straipsnis (teisè ị veiksmingą teisinę gynybą ir teisingą bylos nagrinejjimą). Pažymėtina, kad Chartijos 47 straipsnis atspindi EŽTK 6 ir 13 straipsnių reikalavimus ir todèl siūlo prieglobsčio prašytojams didesnès apimties apsaugą lyginant su Strasbūro apsauga pagal EŽTK 13 straipsnį.

Prieglobsčio prašytojams aktualios EŽTK imperatyvai turi galią ES teisès sistemoje ir remiantis SESV 78 straipsnio 1 dalimi, kuri numato, kad Sajungos kuriama bendra prieglobsčio, papildomos apsaugos ir laikinos apsaugos politika privalo neprieštarauti $1951 \mathrm{~m}$. liepos $28 \mathrm{~d}$. Ženevos konvencijai ir $1967 \mathrm{~m}$. sausio $31 \mathrm{~d}$. Protokolui dèl pabėgèlių statuso bei kitoms atitinkamoms sutartims. Tokioms sutartims neabejotinai priskirtina ir EŽTK.

Atitikties pagrindinėms teisèms reikalavimą atspindi ir antrinė ES prieglobsčio teisè. Pirmiausia, visi prieglobsčio srities teisès aktai skelbia, kad jais gerbiamos pagrindinès teisès ir laikomasi principų, pripažintų visų pirma ES pagrindinių teisių chartijoje ${ }^{160}$. Antros kartos Kvalifikavimo direktyvos ${ }^{161} 34$ konstatuojamaja dalimi papildomai pabrèžiama, kad bendri kriterijai, kuriais remiantis tarptautinès apsaugos prašytojai turi būti pripažistami galinčiais gauti papildomą apsaugą, turètų būti grindžiami tarptautiniais įsipareigojimais pagal žmogaus teisių dokumentus ir valstybių narių praktika. Šia nuostata implicitiškai referuojama ị EŽTK 2 ir 3 straipsnius, kurie neabejotinai buvo ịkvejpimo šaltinis tiek Europos Komisijai, tiek Tarybai apibrèžiant papildomos apsaugos suteikimo ES pagrindus. Kitomis konstatuojamosiomis dalimis pabrěžiamas reikalavimas laikytis šeimos vienybės (pagarbos šeimos gyvenimui) principo pagal Chartiją ir EŽTK

159 Presidency Conclusions of the Cologne European Council of 3 and 4 June 1999, Annex IV [interaktyvus]. [žiūrèta 2013-07-25.]. <http://www.consilium.europa.eu/ueDocs/cms_Data/docs/pressData/en/ec/kolnen. htm>.

160 Žr. Antros kartos Kvalifikavimo direktyvos 16 konstatuojamają dalį, antros kartos Prièmimo sąlygų direktyvos 35 konstatuojamają dali, antros kartos Prieglobsčio procedūrų direktyvos 60 konstatuojamają dali, antros kartos Dublino reglamento 39 konstatuojamają dali.

161 Europos Parlamento ir Tarybos direktyva 2011/95/ES dèl trečiujjų šaliu piliečių ar asmenų be pilietybès priskyrimo prie tarptautinès apsaugos gavejų, vienodo statuso pabėgèliams arba papildomą apsaugą galintiems gauti asmenims ir suteikiamos apsaugos pobūdžio reikalavimų. [2011] OL L337, p. 9-26. 
(Prièmimo sąlygų direktyvos ${ }^{162} 9$ konstatuojamoji dalis, Dublino reglamento ${ }^{163} 14$ konstatuojamoji dalis), pripažįstama, kad valstybèse narėse galimi prieglobsčio prašytojų teisių, išdèstytų Chartijoje, bei kitų žmogaus teisių pažeidimai, kurie galètų kelti pavojų sklandžiam Dublino sistemos veikimui (Dublino reglamento 21 konstatuojamoji dalis), bei konstatuojama, kad dèl elgesio su asmenimis, kuriems taikomas Dublino reglamentas, valstybės narès yra saistomos savo ịsipareigojimų pagal tarptautinès teisès aktus, įskaitant atitinkamą EŽTT praktiką (Dublino reglamento 32 konstatuojamoji dalis).

EŽTK ir EŽTT praktika veikia ES teisyną ir netiesiogiai, nes jos buvo naudojamos kaip įkvėpimo (referencijos) šaltinis rengiant kai kurias prieglobsčio direktyvų nuostatas. Ṣ̌ reiškini geriausiai iliustruoja Europos Komisijos pasiūlymas antros kartos Kvalifikavimo direktyvai, kuriame pabrèžiamas būtinumas užtikrinti, kad šioje direktyvoje ịtvirtinta vidaus apsaugos sąvoka atitiktų EŽTK 3 straipsnị, kaip išaiškinta EŽTT sprendime Salah Sheekh byloje ${ }^{164} .2011$ m. gruodžio 13 d. prièmus Europos Parlamento ir Tarybos direktyvą 2011/95/ES Salah Sheekh vidinio perskèlimo alternatyvos taikymo testas tapo rašytinès antrinès ES prieglobsčio teisès dalimi.

Aptartos ES teisès sistemos nuostatos ir principai iš pirmo žvilgsnio suteikia ESTT ir nacionaliniams teismams reikalingas priemones, kuriomis jie gali užtikrinti EŽTK saugomų teisių apsaugą taikant ES prieglobsčio teisyną. Tačiau vien formalus požiūris gali būti klaidinantis. Liuksemburgo ir Strasbūro sistemos skiriasi keliais esminiais bruožais. Pirma, skiriasi Teismų dispozicijoje esančios teisinès medžiagos pobūdis ir apimtis. Strasbūro jurisprudencija buvo išvystyta vos kelių lakoniškai suformuluotų Konvencijos nuostatų pagrindu. Liuksemburgo teismas yra atsakingas už didžiulès apimties teisinę medžiagą, kuri atspindi tiek žmogaus teisių apsaugos, tiek kovos su piktnaudžiavimu procedūromis ir teisèmis siekius. Todèl ESTT neišvengiamai tenka derinti skirtingus interesus. Antra, skirtingai nei Strasbūro teisme, kuriame pilietinei visuomenei atstovaujančios organizacijos ir JTVPK gali dalyvauti nagrinejjant bylas, tiesiogiai aiškindamos Teismui savo poziciją bei dalyvaudamos ginčuose su valstybių atstovais, Liuksemburgo teisme vykstančioje diskusijoje vyrauja valstybių narių pozicijos. Teisės pateikti savo poziciją Teismui amicus curiae forma nei JTVPK, nei NVO neturi. Būtent todèl JTVPK buvo priverstas daryti viešus pareiškimus dèl konkrečių bylų, taip bandydamas komunikuoti ESTT savo poziciją. Pastaruoju metu JTVPK ir NVO rado elegantišką būdą tapti ESTT proceso dalyviais ịsitraukdami ị bylą jau nagrinèjimo nacionaliniame teisme stadijoje ir įgydami teisę būti pakviesti ị Liuksemburgą ${ }^{165}$.

162 Europos Parlamento ir Tarybos direktyva 2013/33/ES, kuria nustatomos normos dèl tarptautinès apsaugos prašytojų priẻmimo. [2013] OL L 180, p. 96-116.

163 Europos Parlamento ir Tarybos reglamentas (ES) Nr. 604/2013, kuriuo išdèstomi valstybės narès, atsakingos už trečiosios šalies piliečio arba asmens be pilietybès vienoje iš valstybių narių pateikto tarptautinès apsaugos prašymo nagrinèjimą, nustatymo kriterijai ir mechanizmai. [2013] OL L180, p. 31-59.

164 Pasiūlymas Europos Parlamento ir Europos Tarybos direktyvai dèl trečiųų šalių piliečių ar asmenų be pilietybės priskyrimo prie tarptautinès apsaugos gavejjų bei jų statuso ir suteikiamos apsaugos pobūdžio būtiniausių reikalavimų (nauja redakcija). [2009] COM 551, p. 7.

165 Pavyzdžiui, N. S. byloje ESTT procedūroje dalyvavo Amnesty International, AIRE (Advice on Individual Rights in Europe - Konsultavimo individualių teisių klausimais Europoje centras), JK ir JTVPK. 
Svarbu pabrèžti ir tai, kad ESTT, kuris savo pirmą prieglobsčio bylą išnagrinèjo 2009 m. sausio 24 d., yra labai jauna prieglobsčio bylas sprendžianti jurisdikcija lyginant su EŽTT arba autoritetingais nacionaliniais teismais, tokiais kaip Vokietijos federalinis administracinis teismas arba Jungtinès Karalystės teismai. Akivaizdu, kad ES teismas, nagrinėdamas prieglobsčio bylas, mokosi, igydamas patirties ir ieškodamas šaltinių, kurie jam galètų padèti aiškinti prieglobsčio teisyne ịtvirtintą terminiją. Kai kuriais atvejais ES teismo žvilgsnis nukreipiamas ị EŽTT jurisprudenciją.

ESTT išnagrinètos bylos leidžia pateikti pirmas įžvalgas dèl šio teismo teikiamos apsaugos apimties bet turinio ir santykio su EŽTK praktika.

Elgafaji byloje ESTT tiesiogiai patvirtino, kad nustatant EŽTK įtvirtintos teisès apimtị Bendrijos teisès sistemoje turi būti atsižvelgiama į EŽTT praktiką, o nuostatas, kurios nėra identiškos EŽTK numatytoms teisèms, būtina aiškinti nepažeidžiant EŽTK reikalavimų ${ }^{166}$. Šiuo principu ESTT atvèrẻ Strasbūro jurisprudencijai potencialiai platų kelią įsilieti ị bendrą ES prieglobsčio sistemą ir dalyvauti formuojant ES teisyno nuostatų igyvendinimo praktiką. Manytina, kad šio principo potencialas gali atsiskleisti keliomis formomis. Pirma, Kvalifikavimo direktyvos 15 straipsnio a ir b punktuose įtvirtinti papildomos apsaugos suteikimo pagrindai ${ }^{167}$ turètu apimti visus atvejus, kuriems pagal EŽTK 2 ir 3 straipsnius aiškinančią EŽTT praktiką suteikiama apsauga nuo išsiuntimo. Antra, tiek prieglobsčio prašytojams, tiek papildomą apsaugą gavusiems asmenims teikiama apsauga nuo išsiuntimo pagal Kvalifikavimo direktyvos 21 straipsnio 1 dalị turètų būti bent jau identiška apsaugai, garantuojamai EŽTT. Trečia, taikant tarptautinès apsaugos pagrindus, kurie nèra identiški EŽTK, teikiama apsauga savo apimtimi negali būti siauresnè, nei siūloma Strasbūro sistemoje ${ }^{168}$. Ketvirta, EŽTT praktikoje suformuluoti saugikliai, kurių turi būti laikomasi grąžinant asmenị ị trečiąą (tranzito) valstybę, turi būti visiškai prieinami prieglobsčio prašytojui, kuriam taikomas Dublino reglamentas ir (ar) Prieglobsčio procedūrų direktyva.

$N$. S. byla, kurioje buvo svarstoma, ar pagrindinių teisių pažeidimo grèsmė gali suponuoti valstybės narès pareigą susilaikyti nuo asmens perdavimo ,atsakingajai valstybei“ pagal Dublino reglamentą ${ }^{169}$, demonstruoja ESTT pasirengimą visiškai pritarti EŽTT pozicijai tais atvejais, kai faktine situacija patenka ị abiejų sistemų taikymo sritị. Pažymètina, kad Liuksemburgo teismas išnagrinèjo šią bylą $2011 \mathrm{~m}$. gruodžio 21 d., t. y. praejjus 11 mėnesių po EŽTT sprendimo M. $S$. $S$ byloje. Turèdamas prieš akis Strasbūro kolegų argumentus Liuksemburgo teismas suformulavo esminius principus, kuriais remiantis valstybės privalo užtikrinti prieglobsčio prašytojų pagrindinių teisių apsaugą taikant Dublino reglamentą:

166 Elgafaji, 28 pnk.

167 Pagal Kvalifikavimo direktyvos 15 str. a ir b punktus papildomos apsaugos suteikimo pagrindams priskirtini: mirties bausmė ar egzekucija bei kankinimas, nežmoniškas ar žeminamas elgesys arba baudimas kilmès šalyje.

168 Pavyzdžiui, sprendimas nesuteikti apsaugos pagal Kvalifikavimo direktyvos 15 str. c punktą negali sukelti EŽTT 3 straipsnio pažeidimo.

169 Tarybos reglamentas (EB) Nr. 343/2003, nustatantis valstybès narès, atsakingos už trečiosios šalies piliečio vienoje iš valstybių narių pateikto prieglobsčio prašymo nagrinèjimą, nustatymo kriterijus ir mechanizmus. [2003] OL L50, 225, p. 1-10. 
1. Nors Dublino sistema grindžiama prielaida, kad prieglobsčio prašytojams kiekvienoje valstybeje narèje taikoma tvarka atitinka Chartijos, $1951 \mathrm{~m}$. konvencijos ir EŽTK reikalavimus, ši prezumpcija nèra nenuginčijama. Prieglobsčio procedūros ir prieglobsčio prašytojų priẻmimo sąlygų trūkumai atsakingoje valstybèje narèje gali lemti nežmonišką arba žeminantị elgesi pagal Chartijos 4 straipsnį.

2. Valstybès narès privalo susilaikyti nuo prieglobsčio prašytojo perdavimo ,atsakingai valstybei narei“", kai sisteminiai prieglobsčio procedūros ir prieglobsčio prašytojų priemimo sąlygų tokioje valstybeje nareje trūkumai yra rimta ir pagrịsta priežastis manyti, jog prašytojui kils reali nežmoniško ar žeminamo elgesio grèsmè. Tokia grèsmė laikoma nustatyta, kai valstybės narès, įskaitant nacionalinius teismus, negali nežinoti apie sisteminius prieglobsčio procedūros ar prièmimo sistemos trūkumus ${ }^{170}$.

Darydamas šias išvadas, kurios savo esme atkartoja EŽTT poziciją $M$. $S$. S. byloje, ESTT tiesiogiai nurodè ị Strasbūro teismo sprendimą, pabrèždamas situacijų panašumą bei priimdamas EŽTT nustatytą pagrindinių teisių pažeidimo lygi ir naudotą faktų nustatymo metodologiją, pirmiausia informacijos apie padėtį Graikijoje šaltinius. Pažymėtina, kad Sajungos teisès aktų leidèjai priimdami antros kartos Dublino reglamentą patvirtino EŽTT įkvėptą $N$. S. formulę teisèkūros lygmeniu. $2013 \mathrm{~m}$. birželio 26 d. priimto reglamento (ES) Nr. 604/2013 3 straipsnio 2 dalis numato, kad jei prašytojo neịmanoma perduoti pirmajai paskirtai atsakingai valstybei narei, nes esama pagrịstu priežasčių manyti, kad tos valstybės narès prieglobsčio procedūra ir prašytojų prièmimo sąlygos turi sisteminių trūkumų, dẻl kurių esama nežmoniško ar žeminančio elgesio, kaip apibrèžta ES pagrindinių teisių chartijos 4 straipsnyje, rizikos, atsakingos valstybès narès nustatymo procedūrą atliekanti valstybė narė toliau nagrinèja III skyriuje išdèstytus kriterijus, kad nustatytų, ar kita valstybè naré galètų būti paskirta atsakinga. Tokiu būdu EŽTT jurisprudencija ịsiliejo ị ES teisę iš esmès prisidèdama prie fundamentalių principų, kuriais grindžiama Dublino sistema, performulavimo.

$K^{171}$ byloje, kurioje ESTT vèl teko nagrinèti atsakingos valstybès nustatymo kriterijus pagal Dublino reglamentą, Teismas elgèsi kitaip. Skirtingai nei $N$. S. byloje, ESTT neskyrè dėmesio Chartijoje įtvirtintoms teisėms ar EŽTT jurisprudencijai, nors bylos aplinkybės akivaizdžiai kvietė pasisakyti nežmoniško elgesio ir teisès ị šeimos gyvenimą klausimais ${ }^{172}$. Nacionalinio teismo pateiktas klausimas, ar EŽTK 3 ir 8 straipsniai (Chartijos 4 ir 7 straipsniai) gali lemti draudimą perduoti prašytoją atsakingai valstybei ir ar tokiu atveju gali būti taikomos nuo EŽTT praktikos nukrypstančios platesnès, „nežmoniško elgesio“ ar ,šeimos“ sąvokos liko neatsakytas. Vietoj to Teismas išaiškino reglamento 15 straipsnio 2 dalyje ịtvirtintą humanitarinę išlygą, kaip ịpareigojančią valstybes leisti likti kartu prieglobsčio prašytojui ir kitam jo giminaičiui neapsiribojant siaura šeimos narių sąvoka, jei atitinkamas asmuo yra priklausomas nuo kito dèl sunkios

170 N. S. ir M. E. ir kt., 80, 104 ir 106 pnk.

171 Byla C-245/11, K prieš Bundesasylamt.

172 Kaip pabrèžiama sprendime, pareiškejjos K marti yra nuo jos priklausoma dèl sunkios ligos ir didelès negalios, atsiradusios dèl patirto traumą sukèlusio įvykio. K tapo artimiausia marčios patarèja ir draugè, kuri padëjo jai rūpintis vaikais (16 pnk.). Tačiau pagal Dublino reglamento ịtvirtintus atsakingos valstybès nustatymo kriterijus K turejo būti perduota kitai ES valstybei. 
ligos ar didelès negalios, t. y. iš esmès išspręsdamas bylą pareiškejjos naudai. Tačiau toks plečiamasis antrinès teisès aiškinimas, nors ir sustiprina jos apsaugos potencialą, pasižymi pažeidžiamumu, nes valstybės narès aktyviai dalyvaudamos teisės kūrimo procese gali koreguoti antrinę teisę, eliminuodamos arba apribodamos teismo nustatytus apsaugos standartus. Būtent tai atsitiko Teismo išvadoms $K$ byloje, nes prièmus antros kartos Dublino reglamentą kitų giminaičių sąvoka, kuria Teismas rèmėsi savo analizėje, buvo pakeista. Tokiu būdu antros kartos reglamento prièmimas lėmé žymesnio lygio standarto nustatymą lyginant su ESTT pateiktu išaiškinimu ${ }^{173}$.

Byloje MA ir kiti ${ }^{174}$ nacionalinis teismas pasiūle ESTT atsakyti ị klausimą, kaip turètų būti aiškinama Dublino reglamento 6 straipsnio antroje pastraipoje įtvirtinta nuostata, kad, nesant teisètai kurioje nors valstybejje narèje gyvenančio nelydimo nepilnamečio šeimos nario, „už prašymo nagrinèjimą yra atsakinga ta valstybè narè, kurioje nepilnametis yra pateikęs prieglobsčio prašymą", kai nelydimas nepilnametis pateikè prieglobsčio prašymus daugiau nei vienoje valstybejje nareje. Nors ESTT pateikta analizė pirmiausia grindžiama reglamento tekstu, kontekstu bei tikslais, kurie, teismo nuomone, rodo, kad už prašymo nagrinėjimą turètų būti atsakinga valstybè, kurioje vaikas pateike paskutini prašymą ${ }^{175}$, skirtingai nei $K$ byloje, ESTT neapsiribojo anksčiau minètais aiškinimo metodais, papildomai nurodydamas ị konstatuojamosios dalies reikalavimus, pagal kuriuos reglamente laikomasi pagrindinių teisių, bei pabrěždamas, kad nagrinèjamą reglamento nuostatą negalima aiškinti taip, kad ji pažeistų Chartijos 24 straipsnio 2 dalimi įtvirtintą geriausių vaiko interesų principą ${ }^{176}$. Ši byla rodo teismo pasirengimą naudoti pagrindinių teisių reikalavimus kaip teisès aiškinimo priemonę užpildant antrinëje teisèje esamas spragas bei šalinant jos neaiškumus. Šis metodas neabejotinai sustiprina teisyno teikiamos apsaugos turini, nes teismo nurodyta atitinkamos antrinè teisès nuostatos reikšme iš esmès pavirsta iš pirminès teisès išplaukiančiu imperatyvu, kuris negali būti lengvai eliminuojamas keičiant atitinkamo teisès akto tekstą.

Kadzoev ${ }^{177}$ ir Arslan $^{178}$ bylose ESTT nagrinėjo prieglobsčio prašytojų sulaikymo problematiką. Nors abi bylos buvo tiesiogiai susijusios su iš teisès ị laisvę išplaukiančių reikalavimų aiškinimu, priimdamas sprendimus Teismas nebuvo linkęs pasinaudoti savo paties suformuluotu principu, kad siekiant apibrèžti pagrindinès teisès taikymo apimtị reikia atsižvelgti ị EŽTT praktiką ${ }^{179}$. EŽTT jurisprudencija pagal 5 straipsnị liko nepastebèta. Vis dèlto Kadzoev byloje tai nesutrukde Teismui nustatyti kelis svarbius saugiklius, kuriais neabejotinai sustiprinama apsauga nuo neteisèto sulaikymo ES teisès sistemoje. Pirmiausia tai pasakytina apie teismo išvadą, kad Direktyvos 2008/115 (Grą-

173 Steve Peers, Statewatch analysis: The second phase of the Common European Asylum System: A brave new world - or lipstick on a pig? April 2013, 7 p. [interaktyvus]. [žiūrèta 2013-07-29]. <http://www. statewatch.org/analyses/no-220-ceas-second-phase.pdf>.

174 Byla C-648/11, The Queen, prašoma MA ir kiti prieš Secretary of State for the Home Department.

175 MA ir kiti, 50-55 pnk.

176 Ibid., 56-57 pnk.

177 Byla C-357/09 PPU, Said Shamilovich Kadzoev (Huchbarov).

178 Byla C-534/11, Mehmet Arslan prieš Policie ČR, Krajské reditelství policie Ústeckého kraje, odbor cizinecké policine.

179 Byla C-94/00, 29 pnk. 
žinimo direktyvos) ${ }^{180} 15$ straipsnio 5 ir 6 dalyse numatytų maksimalių sulaikymo terminų paskirtis - nustatyti asmens laisvès atèmimo ribas ir kad, pasibaigus maksimaliam sulaikymo terminui, direktyva neleidžia nepaleisti suinteresuotojo asmens nedelsiant, motyvuojant, kad jis neturi galiojančių dokumentų, elgiasi agresyviai ir neturi nei nuosavų pragyvenimo lèšų, nei būsto, nei valstybès narès šiam tikslui suteiktos paramos ${ }^{181}$. Toks rezultatas gali būti iš dalies paaiškinamas tuo, kad Grąžinimo direktyvos nuostatos dèl sulaikymo yra pakankamai aukšto lygio žmogaus teisių apsaugos požiūriu. Jų tekstas buvo inter alia paremtas Europos Tarybos gairèmis dèl priverstinio grąžinimo ${ }^{182}$, kurios buvo rengiamos atsižvelgiant ị EŽTT jurisprudenciją. Ši teisinè medžiaga neabejotinai ịgalina Teismą vystyti praktiką, orientuotą ị teisès ị laisvę apsaugos saugiklius. Tačiau vėlgi, kaip jau pabrežta, toks metodas nėra apsaugotas nuo galimos vẻlesnès ES teisès aktų leidejjų intervencijos.

Arslan byla atskleidžia kitus pavojus. Šioje byloje nacionalinis teismas siekè sužinoti, ar, nepaisant to, kad Grąžinimo direktyva netaikoma prieglobsčio prašytojams, prieglobsčio prašymą pateikęs asmuo gali likti sulaikytas, jeigu jis savo prašymą padavė būdamas sulaikytas išsiuntimo tikslu pagal Grąžinimo direktyvą. Skitingai nei Kadzoev atveju, šioje byloje teismas neturèjo savo dispozicijoje kokybiškos teisinès medžiagos, nes pirmos kartos prieglobsčio direktyvų nuostatos dẻl sulaikymo pasižymi itin dideliu neapibrèžtumu. Tokioms nuostatoms priskirtinas Prièmimo sąlygų direktyvos 7 straipsnis, kuris leidžia valstybèms nacionalinės teisès nustatyta tvarka sulaikyti prieglobsčio prašytoją, „kai yra tikslinga, pavyzdžiui, dèl teisinių priežasčių arba viešosios tvarkos sumetimais", bei Prieglobsčio procedūrų direktyvos 18 straipsnis, kuriuo valstybėms draudžiama sulaikyti asmeni ,,tik dèl priežasties, kad jis yra prieglobsčio prašytojas“ ir reikalaujama sulaikymo atveju užtikrinti ,greito teisminio svarstymo galimybę“. Pastebeję̨s, kad pirmos kartos prieglobsčio direktyvomis nėra suderinti prieglobsčio prašytojų sulaikymo pagrindai, ESTT pažymèjo, kad būtent valstybės narès „turi nustatyti priežastis, dèl kurių prieglobsčio prašytojas gali būti sulaikytas ar jo sulaikymas pratęstas ${ }^{\text {“183 }}$. EŽTT nepateike iš teisès ị laisvę kylančių reikalavimų, kuriuos turètų atitikti tokios nacionalinės nuostatos, o apsiribojo pastebejjimu, kad nustatydamos sulaikymo priežastis valstybės narès privalo tinkamai laikytis ịsipareigojimų pagal tarptautinę teisę ir Sajungos teisę ${ }^{184}$ bei konstatavo, kad Prièmimo sąlygų ir Prieglobsčio procedūrų direktyvomis nedraudžiama, kad asmuo, padavęs prieglobsčio prašymą, po to, kai buvo sulaikytas remiantis Grąžinimo direktyva, būtų toliau sulaikytas pagal nacionalinę teisę, kai paaiškejja, kad šis prašymas pateiktas vien siekiant pavèlinti ar sutrukdyti įvykdyti sprendimą grąžinti, ir kad objektyviai būtina sulaikymo priemonę palikti galioti, siekiant neleisti,

180 Europos Parlamento ir Tarybos direktyva 2008/115/EB dèl bendrų nelegaliai esančių trečiųų šalių piliečių grąžinimo standartų ir tvarkos valstybèse narèse. [2008] OL L 348, p. 98-107.

181 Kadzoev, 56 or 71 pnk.

182 Twenty Guidelines of the Commitee of Ministers of the Council of Europe on Forced Return, September 2005 [interaktyvus]. [žiūrèta 20013-07-31]. <http://www.coe.int/t/dg3/migration/archives/Source/MalagaRegConf/20_Guidelines_Forced_Return_en.pdf $>$.

183 Arslan, 56 pnk.

184 Ibid. 
kad šis asmuo visiškai išvengtų grąžinimo priemonès taikymo ${ }^{185}$. Šia išvada ESTT faktiškai suformulavo sulaikymo pagrindą, kurị valstybès galètų įtvirtinti savo nacionalinèje teisèje, t. y. atliko galimos nacionalinès teisès nuostatos atitikties Sajungos teisei išankstinę kontrolę. Nuostabą kelią tai, kad pateikdamas savo formuluotę ESTT tiesiogiai nepatikrino, ar ji atitinka teisès ị laisvę apsaugos imperatyvus, t. y. neįsitikino, kad jis, vartojant paties ESTT posakį, „nesivadovauja tokiu antrinės teisès teksto aiškinimu, kuris pažeistų Sajungos teisès sistemos saugomas pagrindines teises ${ }^{\text {(186 }}$.

ESTT rėmėsi pagrindinėmis teisėmis išaiškindamas Kvalifikavimo direktyva ${ }^{187}$ įtvirtintus tarptautinès apsaugos suteikimo pagrindus. Pirmiausia išskirtinas Teismo suformuluotas principas, kuriuo reikalaujama, kad Kvalifikavimo direktyva būtų aiškinama laikantis inter alia SESV 78 straipsnio 1 dalyje minimų ,svarbių sutarčių“ bei atsižvelgiant ị teises, pripažintas pagal Chartiją ${ }^{188}$. Y ir $Z^{189}$ byloje šis bendras principas buvo pritaikytas aiškinant pabėgèlio sąvokos požymius, būtent persekiojimo dèl religijos požymius. Išskirtini keli ESTT panaudotos argumentacijos aspektai. Pirma, ESTT tiesiogiai rèmėsi Chartijos 10 straipsnio 1 dalyje ịtvirtinta religijos laisve ${ }^{190}$, kurią iš esmès naudojo kaip saugomos vertybès standartą, kartu pabrèždamas, kad Chartijoje numatyta religijos laisvè ,atitinka EŽTK 9 straipsnyje garantuojamą teisę“. Antra, ESTT nepritarė religijos laisvės išskyrimui persekiojimo sąvokos požiūriu ỉ ,pagrindinę sritị““ (forum internum) ir viešają religinę veiklą (forum externum). Todèl veiksmai, kurie gali būti laikomi persekiojimu, turi būti nustatomi ne pagal pažeistos religijos laisvès aspektus, bet pagal asmens atžvilgiu vykdytų represijų pobūdị ir jų pasekmes ${ }^{191}$. Trečia, Teismas pateikè galimas persekiojimo dèl religijos formas, konstatuodamas, kad teisès ì religijos laisvę pažeidimas gali būti persekiojimas, kai asmuo dèl to, kad ịgyvendina šią laisvę, patiria realią riziką, be kita ko, būti patrauktam baudžiamojon atsakomybèn (angl. prosecuted), kankinamam, patirti nežmonišką ar žeminančią bausmę ${ }^{192}$. Šia pozicija Teismas iš esmès pademonstravo pasiryžimą teikti apsaugą asmenims, kurie savo kilmės valstybėse negali pasinaudoti Chartijos 10 straipsnio 1 dalyje numatytomis garantijomis. Šs persekiojimo sąvokos aiškinimas neabejotinai paremtas žmogaus teisių apsaugos standartais ir, jei bus vystomas toliau, gali sąlygoti geresnị apsaugos prieinamumą prieglobsčio prašytojams valstybèse narèse.

185 Arslan, 63 pnk.

186 N. S. ir M. E. ir kt. 77 p.

187 Tarybos direktyva 2004/83/EB dèl trečiujų šalių piliečių ar asmenų be pilietybės priskyrimo pabėgèliams ar asmenims, kuriems reikalinga tarptautinė apsauga, jų statuso ir suteikiamos apsaugos pobūdžio būtiniausių standartų. [2004] OL L304, 9 30, p. 2-2.

188 Sujungtos bylos C-175/08, C-176/08, C-178/08 ir C-179/08, Aydin Salahadin Abdulla (C-175/08), Kamil Hasan (C-176/08), Ahmed Adem, Hamrin Mosa Rashi (C-178/08) ir Dler Jamal (C-179/08) v. Bundesrepublik Deutschland, 53 ir 54 pnk.

189 Sujungtos bylos C-71/11 ir C-99/11, Bundesrepublik Deutschland v. Y (C-71/11) ir Z (C-99/11),

190 Chartijos 10 straipsnio 1 dalis skelbia: „Kiekvienas turi teisę ị minties, sąžinès ir religijos laisvę. Ši teisè apima laisvę keisti savo religiją ar tikèjimą, taip pat laisvę išpažinti ir skelbti savo religiją ar tikejjimą tiek vienam, tiek kartu su kitais, viešai ar privačiai, laikant pamaldas, mokant tikèjimo, ji praktikuojant ar atliekant apeigas."

191 Y ir Z, 65 pnk.

192 Ibid., 66 ir 72 pnk. 
Samba Diouf ${ }^{93}$, M. M. ${ }^{194}$ ir H. I. D. ${ }^{195}$ bylos rodo, kad ESTT yra pasiruošęs skirti pakankamai svarų vaidmenị pagrindinėms teisèms aiškinant prieglobsčio prašymų nagrinëjimo procedūroms taikytinus reikalavimus. Šiame kontekste pirmiausia išskirtinos Chartijos nuostatos, kuriomis kodifikuoti administracinèms procedūroms ir sprendimams taikomi bendrieji ES teisès principai. M. M. byla yra itin svarbi, nes joje ESTT, remdamasis Chartijos 41 straipsnio 2 dalyje ịtvirtinta teise būti išklausytam prieš taikant asmeniui bet kokią individualią nepalankią priemonę, konstatavo, kad ši teisė „yra visuotinai taikoma“ ir "turi būti visiškai taikoma kompetentingos nacionalinės institucijos pagal bendrają Europos prieglobsčio sistemą priimtas taisykles organizuojamoje prašymo [...] nagrinèjimo procedūroje “196. Nors Teismas nedetalizavo, kokia forma ši teisè turi būti užtikrinta prieglobsčio prašytojui (t. y. žodžiu ar raštu), teisès būti išklausytam absoliutus pripažinimas prieglobsčio prašytojams pirminès teisès pagrindu neabejotinai eliminavo galimybę valstybėms priimti sprendimą dèl prieglobsčio prašymo apskritai nesuteikiant asmeniui progos pasisakyti dèl prašymo pagrindo sudarančiu aplinkybių. Pažymėtina, kad 2013 m. birželio 26 d. priimta antros kartos Prieglobsčio direktyva ${ }^{197}$ atspindi šį požiūrị, nes ja buvo panaikintos antrinès teisès nuostatos, leidžiančios nesuteikti prieglobsčio prašytojui asmeninio pokalbio galimybès. Ši ES prieglobsčio teisyno evoliucija neabejotinai turètų sustiprinti valstybės narių nacionalinių prieglobsčio procedūrų suderinamumą su EŽTK veiksmingos teisinès gynybos imperatyvais, kaip jie aiškinami EŽTT praktikoje taikant EŽTK 3 ir 13 straipsnius. Samba Diouf ir H. I. D. bylose ESTT buvo pakviestas pasisakyti paspartintų prieglobsčio procedūrų klausimais. Teismo argumentacija leidžia konstatuoti, kad nors valstybės naudojasi plačia diskrecija spręsdamos, kokios konkrečios procedūros ir kokiais pagrindais gali būti taikomos nagrinejjant prieglobsčio prašymus, ši veikimo laisvè nèra neribota, nes jos privalo visose procedūrose tiek de jure, tiek de facto užtikrinti Prieglobsčio procedūrų direktyvos ${ }^{198}$ II skyriuje įtvirtintus pagrindinius procesinius principus ir garantijas, atspindinčias direktyvoje deklaruojamą sąžiningų procedūrų siekị $i^{199}$. Funkciniu požiūriu šie principai ir garantijos užtikrina iš direktyvos 8 konstatuojamosios dalies išplaukiantị reikalavimą, kad prieglobsčio procedūra „,būtų pagrịsta pagarba pagrindinėms teisėms ir principams, kurie pirmiausia yra pripažinti chartijoje ${ }^{\text {“200. }}$. Todèl taikant pagreitinto nagrinejjimo procedūrą prieglobsčio prašytojams turi būti leidžiama visiškai pasinaudoti direktyvoje įtvirtintomis prieglobsčių prašytojų teisėmis. Anot Teismo, prašytojai turi inter alia galèti ,pasinaudoti pakankamu laikotarpiu, kad galètų surinkti ir pateikti ịrodymus, reika-

193 Byla C-69/10, Brahim Samba Diouf prieš Ministre du Travail, de l'Emploi et de l'Immigration

194 Byla C-277/11, M. M. prieš Minister for Justice, Equali ty and Law Reform, Ireland ir Attorney General

195 Byla C-175/11, H. I. D. ir B. A. prieš Refugee Applications Commissioner ir kt.

196 M. M., 89 pnk.

197 Europos Parlamento ir Tarybos direktyva 2013/32/ES dèl tarptautinès apsaugos suteikimo ir panaikinimo bendros tvarkos. [2013] OL L 180, 629 , p. 60-95.

198 Tarybos direktyva 2005/85/EB, nustatanti būtiniausius reikalavimus dèl pabėgèlio statuso suteikimo ir panaikinimo tvarkos valstybèse narèse. [2005] OL L326, p. 13-34.

199 Biekša, L.; Siniovas, V. Sąžiningos ir veiksmingos prieglobsčio procedūros beieškant: Lietuvos pastangos igyvendinti Tarybos direktyvą 2005/85/EB. Etniškumo studijos. 2013,1: 55.

200 H. I. D., 58 pnk, Samba Diouf, 61 pnk. 
lingus jų prašymams pagrįsti, ir taip leistų sprendžiančiajai institucijai teisingai (angl. fair) ir visapusiškai (angl. comprehensive) išnagrinėti šiuos prašymus bei įsitikinti, kad prašytojams nekyla pavojus jų kilmės šalyse“201. Nacionalinis teismas, nagrinėdamas skundą dèl sprendimo nesuteikti prieglobsčio, turi patikrinti, ar nagrinèjant prašymą buvo laikomasi pagrindinių principų ir garantijų ${ }^{202}$. Ivardydamas šiuos principus ESTT nesirèmė EŽTT jurisprudencija dėl EŽTK 3 ir 13 straipsnių. Vis dèlto ESTT pateikti išaiškinimai atspindi kelis esminius saugiklius, pripažintus EŽTT praktikoje, tokius kaip: išsamaus nagrinejjimo reikalavimas, galimybès pateikti prašymą suteikimas, informacijos apie procedūrą suteikimas, ir trumpų ar nelanksčių procesinių terminų draudimas. Kita vertus, reikalaudamas, kad valstybès užtikrintų procesinius principus ir garantijas pagreitinto nagrinejjimo procedūrose, ESTT kol kas tik iš dalies pripažino, kad pačios procedūros organizaciniai aspektai gali de facto neleisti pasinaudoti deklaruojamomis garantijomis, ypač dẻl kumuliatyvaus jų poveikio asmeniui. Pirmą žingsni šia linkme ESTT žengè H. I. D. byloje pabrèždamas, kaip jau buvo nurodyta, kad taikytinas nagrinèjimo terminas turi leisti asmeniui pateikti įrodymus, o valstybės institucijai - išsamiai išnagrinėti prašymą. Šis požiūris turi didelị potencialą vystant pagreitinto nagrinèjimo procedūroms taikytinus reikalavimus. Todẻl ateityje galima tikètis įdomių pokyčių Teismo praktikoje, ypač jei ESTT pasinaudos Strasbūro teismo įžvalgomis dèl pagreitinto nagrinèjimo procedūrų atitikties EŽTK 3 ir 13 straipsniams. I. M. prieš Pranzūciją, kurioje EŽTT pripažino, kad nacionalinė procesinè sistema savo visuma (angl. as a whole) neužtikrino veiksmingos teisès gynimo priemonès, kuri būtų praktiškai veiksminga ${ }^{203}$, yra pavyzdys jurisprudencijos, kuri tikrai galètų praturtinti ESTT analizę.

Nepaisant nedidelio išnagrinètų bylų, susijusių su prieglobsčiu, skaičiaus, ESTT jau turèjo progą pasisakyti dẻl nacionalinėms apeliacinėms sistemoms taikytų reikalavimų veiksmingos teisminès gynybos principo požiūriu. Pirmiausia Teismas yra pabrèžęs, kad šis principas yra bendrasis Sajungos teisès principas, kuris šiuo metu įtvirtintas Chartijos 47 straipsnyje $\mathrm{e}^{204}$. Tai leido ES teismui ịvardinti nacionalinėms sistemoms taikytinus reikalavimus remiantis ne tik Prieglobsčio procedūrų direktyvos 39 straipsniu, kuriuo ịtvirtinama teise ị veiksmingą teisès gynimo priemonę, bet ir savo ankstesne praktika, išvystyta kitose teisyno srityse. Vienas įdomesnių šio požiūrio rezultatų yra ESTT konstatavimas, kad nagrinëjant skundus dẻl sprendimų nesuteikti prieglobsčio nacionalinis teismas privalo atlikti sprendimo kontrolę tiek faktų, tiek teisès požiūriu ${ }^{205}$. Šia išvada ESTT suteikė ES prieglobsčio procedūroms taikomam teisinės gynybos principui turinị, kuris savo apsaugos potencialu iš dalies pranoksta standartus, kuriuos siūlo prieglobsčio prašytojams EŽTT, taikydamas EŽTK 13 straipsnį. Samba Diouf byloje ESTT turèjo galimybę nustatyti reikalavimus dẻl skundo pateikimo terminų trukmès. Anot teismo, vertinant, ar terminas yra protingas ir proporcingas, ,svarbiausia [...], kad

201 H. I. D., 58 pnk, Samba Diouf, 75 pnk.

202 Samba Diouf, 61 pnk.

203 I. M. v. France, Appl. No. 9152/09, European Court of Human Rights, Judgement, 02-02-2012, 136-160 pnk.

204 Samba Diouf, 48 pnk., H. I. D., 80 pnk.

205 Ibid., 57 pnk. 
turimo laiko realiai pakaktų veiksmingai teisinei gynybai parengti ir skundui pateikti“ ${ }^{\circledR 206}$. Veiksmingos teisminès gynybos principas negarantuoja teisès ị procedūrą keliose instancijose. Todèl vienos instancijos teismo atlikta kontrolè yra pakankama, jeigu ji atitinka veiksmingai teisès gynimo priemonei taikomus reikalavimus ${ }^{207}$. Kita vertus, apeliacinè sistema, kurią sudaro kelios instancijos, gali garantuoti teisę ị veiksmingą teisinę gynybą, net jeigu apeliacinè institucija, nagrinejjanti skundus dèl sprendimų nesuteikti prieglobsčio, neatitinka visų teismo požymių, kaip jie yra apibréžti ESTT praktikoje ${ }^{208}$. Ateityje ESTT praktika aiškinant teisę ị teisinę gynybą prieglobsčio procedūrose neabejotinai evoliucionuos ir ịtakos jai didžiaja dalimi turès paties ESTT priimti sprendimai dèl Chartijos 47 straipsnio aiškinimo kitose ES teisyno srityse. Vis dèlto ESTT turès atsižvelgti ir į EŽTT jurisprudenciją, pirmiausia aiškindamas su skundo suspensyviniu poveikiu susijusius klausimus, ypač atsižvelgiant ị tai, kad antros kartos Prieglobsčio procedūrų direktyvoje yra ịtvirtintos detalios nuostatos dèl suspensyvinio skundo poveikio, kurių turinį sparčiai besivystanti Strasbūro praktika turètų padèti išaiškinti.

\section{EŽTK ir ES teisių gynimo mechanizmų vertinimas}

Nors EŽTK ir ES teisių gynimo mechanizmai nèra identiški, vis dẻlto galima juos palyginti atsakant ị klausimą - kuris iš jų palankesnis prieglobsčio prašytojų teisėms ginti? Pirma, lyginant su EŽTK, ES prieglobsčio teisyno reglamentavimo sritis yra platesnès apimties. Todèl ESTT turi galimybę vystyti prieglobsčio prašytojų teisių apsaugos praktiką klausimais, kuriuos nagrinèti EŽTT neturi kompetencijos arba nagrinëja netiesiogiai per atitinkamos EŽTK teisès prizmę. Tokiems klausimams inter alia priskirtini pabėgèlio apibréžimo požymiai, tarptautinès apsaugos netaikymo ir pasibaigimo nuostatos, prièmimo sąlygos ir konkrečios procesinès sąvokos bei nuostatos. Iš esmès, ESTT suteikta kompetencija aiškinti reikalavimus, kurie paliečia visus esminius nacionalinių prieglobsčio sistemų aspektus ir kai kuriais atvejais pasižymi gana intensyviu reglamentavimu, ypač priėmus antros kartos prieglobsčio teisės aktus. Todèl šiuo požiūriu ESTT vykdoma kontrolė yra konkretesnè ir apima platesnị spektrą klausimų, susijusių su prieglobsčio prašytojų kasdieniniu gyvenimu.

Antra, nepaisant atsargaus požiūrio ir pasitaikančių klaidų, ESTT jau pirmose išnagrinètose bylose parodè, kad jo vystoma praktika gali prisidèti prie ị žmogaus teisių apsaugą orientuotą tarptautinès apsaugos suteikimo, netaikymo ir pasibaigimo pagrindų aiškinimo. Šiuo požiūriu inter alia išskirtinos ES teismo pozicijos, kai jis konstatavo, kad Kvalifikavimo direktyvos 15 straipsnio c punktu įtvirtintas papildomos apsaugos pagrindas nereikalauja ,individualios grèsmès nustatymo, jei ginkluoto konflikto metu

206 Samba Diouf, 48 pnk., H. I. D., 66 pnk.

207 Ibid., 69 pnk.

208 H. I. D., 83-105 p. Anot Teismo, sprendžiant, ar prašymą priimti prejudicinį sprendimą pateikusi institucija yra teismas pagal SESV 267 straipsnị, atsižvelgiama ị aplinkybių visumą, t. y. ar institucija ịsteigta remiantis teisės aktais, ar ji nuolatinè, ar jos jurisdikcija yra privaloma, ar jos procesas grindžiamas rungimosi principu, ar ji taiko teisès aktus ir ar ji yra nepriklausoma. 
naudojamas nepasirinktinis smurtas pasiekia atitinkamą lygi““209, kad taikant „sunkaus nepolitinio nusikaltimo“ arba „Jungtinių Tautų siekiams ir principams prieštaraujančių veiksmų“ sąvokas būtina nustatyti asmeninę atsakomybę ${ }^{210}$ ir kad vertindamos aplinkybių pasikeitimą pabėgèlio statuso pasibaigimo nuostatų požiūriu valstybès privalo patikrinti, ar apsaugos teikèjai èmėsi pagrịstų priemonių užkirsti kelią persekiojimui kilmès valstybej $\mathrm{e}^{211}$. Trečia, ESTT procedūra dèl prejudicinio sprendimo paprastai trunka trumpiau, nei bylinėjimasis su valstybe EŽTT, ypač jei ESTT nagrinejja nacionalinio teismo prašymą pagal skubią procedūrą. Kadzoev byloje ESTT sprendimą pagal 2009 m. rugsèjo 7 d. gautą Bulgarijos teismo prašymą prièmė 2009 m. lapkričio 30 d. Kadangi ES teisimo pateiktas išaiškinimas de facto reiškè, kad asmuo turi būti paleistas, akivaizdu, kad klausimas buvo išspręstas iš esmès dalyvaujant ESTT itin operatyviai. Šiuo požiūriu Liuksemburgo sistema pranoksta EŽTT procedūras. Be to, prašymą pateikti prejudicinị sprendimą ESTT gali pateikti bet kuris nacionalinis teismas, o tai reiškia, kad mažèja laiko sąnaudos, kurias asmuo pagal EŽTT procedūras būtų turèjęs skirti vidaus gynybos priemonėms išnaudoti. EŽTT perkrovimas bylomis yra vienas opiausių Teismo reformos klausimų. Iš tiesų, praeina daugybe metų, kol Teismas išnagrinejja bylas, net ir skubiais atvejais. Pareiškejjai taip pat nusivilia susidūrę su realybe vykdant EŽTT sprendimus ${ }^{212}$.

Analizuojant ESTT sistemos trūkumus prieglobsčio prašytojų teisių apsaugos požiūriu reikia pabrèžti, kad Liuksemburgo procedūros kol kas nèra tiesiogiai prieinamos individualiam prieglobsčio prašytojui, kadangi tik nacionaliniai teismai gali kreiptis i ESTT konkrečioje byloje. Todèl de facto prieiga prie ESTT procedūros priklauso nuo nacionalinio teismo vertinimo, kuris nebūtinai gali būti palankus asmens ketinimams pasinaudoti prejudicinio sprendimo procedūromis. Antra, ESTT yra teisę aiškinantis teismas. Jis nepriima sprendimo dèl esmès. Tokị sprendimą priima nacionaliniai teismai, kurie naudojasi diskrecijos teise taikydami ESTT išaiškinimą. Šiame kontekste Strasbūro sistema siūlo prieglobsčio prašytojui žymiai intensyvesnę jo atvejo peržiūrą, kuri apima tiek faktinių aplinkybių tyrimą, pavyzdžiui, padėties kilmės valstybèje ịvertinimą, tiek jų kvalifikavimą atitinkamo EŽTK straipsnio požiūriu. Todėl EŽTT procedūrų teisinis rezultatas yra apibrěžtesnis, jis yra labiau nukreiptas ị konkrečios asmens situacijos, susijusios su išsiuntimo pavojumi, sulaikymu ar šeimos narių išskyrimu, išsprendimą. Trečia, šiuo metu EŽTT bent jau apsaugos nuo išsiuntimo klausimu yra išvystęs solidžią jurisprudenciją su aiškiais kriterijais, kuri ne tik sprendžia konkretaus asmens situaciją, tačiau ir kai kuriais atvejais nurodo tam tikras gaires valstybėms narėms, kaip spręsti sistemines problemas (žr. pilotiniai sprendimai). Nors galima sutikti dèl ES teisių gynimo sistemos operatyvumo, vis dėlto EŽTT proceso ilgumo problemą sušvelnina EŽTT pilotiniai sprendimai, kuriuose vienu sprendimu nurodoma, kaip spręsti bendrą

209 Elgafaji, 43 pnk.

210 Sujungtos bylos C-57/09 ir C-101/09, Bundesrepublik Deutschland prieš B (C-57/09) ir D (C-101/09), 99 pnk.

211 Aydin Salahadin Abdulla ir kt., 76 pnk.

212 The Conscience of Europe: 50 Years of the European Court of Human Rights [interaktyvus]. [žiūreta 2013-07-23]. <http://www.echr.coe.int/Documents/Anni_Book_Chapter13_ENG.pdf>, p. 164. 
problemą visoje šalyje, tokiu būdu vienu sprendimu išsprendžiama daugybẻ bylų (pvz., M. S. S. prieš Graikija bylos sprendimas, kuris priimtas kaip pilotinis sprendimas). Be to, nors EŽTK ir nèra specifinis prieglobsčio teisių gynimo mechanizmas su aiškia kompetencija konkrečiais prieglobsčio klausimais, vis dèlto kai kurios svarbios prieglobsčio teisès nuostatos būtent buvo išaiškintos EŽTT dèka (pvz., Salah Sheek byloje nustatyti vidaus apsaugos vertinimo kriterijai, keliose bylose pripažintas nevalstybinių subjektų vykdomas persekiojimas ir pan.). Būtent EŽTT praktika tapo kai kurių ES prieglobsčio teisès aktų tobulinimo pagrindu. Pagaliau, reikètų nepamiršti ir to, kad papildomos apsaugos pagrindų vystymąsis ES bent jau Kvalifikavimo direktyvos 15 straipsnio a ir b dalies pagrindu itin priklausys nuo EŽTT jurisprudencijos pagal EŽTK 2 ir 3 straipsnį, kurie yra šios apsaugos kertiniai pagrindai. Galiausiai, jei ne EŽTT, nebūtų užtikrintos galimybės ginčyti tam tikrų ES prieglobsčio teisès nuostatų (pvz., Dublino reglamento), kai jų taikymas pažeidžia prieglobsčio prašytojų teises.

\section{Išvados}

1. Labiausiai išvystyta prieglobsčio prašytojų ir pabėgèlių apsaugos forma pagal EŽTK galima vadinti konvencijos 3 straipsnio teikiamą apsaugą nuo išsiuntimo, tačiau šis straipsnis vis dar nèra pakankamu pagrindu ginti su suteikiamu statusu, sustabdžius išsiuntimą, susijusias teises. Konvencijos 13 straipsnis ir susiformavusi Teismo jurisprudencija dèl prieglobsčio prašytojų teisių gynimo akivaizdžiai padeda šalinti daugybę valstybiu prieglobsčio procedūrų trūkumų, todèl yra rimta procesinè atrama daugeliui prieglobsčio prašytojų, kuriems nesuteikiama teisè pasilikti šalyje apskundus neigiamą prieglobsčio sprendimą, teisinė pagalba ir tinkama informacija apie prieglobsčio procedūras. Panašiai 5 straipsnio teikiama apsauga, Teismui pripažistant, kad prieglobsčio prašytojai yra itin pažeidžiami dèl savo specifinès padèties, pakankamai veiksmingai padeda spręsti daugybę sulaikymo problemų valstybėse narèse. Nors užuomazgos dẻl pozityviųų teisių pripažinimo šeimos susijungimo atveju Teismo jurisprudencijoje yra, vis dèlto pabėgèlių apsauga pagal 8 straipsnį vis dar nusileidžia 3 straipsnio apsaugai, kuri vertinama kaip efektyvesnè ir tinkamesnè prieglobsčio prašytojų situacijai.

2. Atsižvelgiant ị ESTT praktiką, tiek ES institucijų priimti teisès aktai, tiek nacionalinės jų taikymo ar ịgyvendinimo priemonès turi atitikti pagrindines teises, įskaitant teises, išplaukiančias iš EŽTT. Tačiau prieglobsčio bylose ESTT taiko šį testą nevienodai. Vienais atvejais Teismas priima sprendimą, apskritai nę̨traukdamas pagrindiniu teisių i savo analizę (Kadzoev, Arslan, $K$ ), kitais atvejais jis remiasi Chartija, kaip papildoma antrinès teisès aiškinimo priemone (MA ir kiti), patikrina, ar jo pateiktas išaiškinimas neprieštarauja EŽTT jurisprudencijai (Elgafaji), ar tiesiogiai vadovaujasi Strasbūro teismo argumentacija ir išvadomis, formuluodamas iš Chartijos kylančius reikalavimus antrinei prieglobsčio teisei ir ją plečiamai aiškindamas (N. S.). Todèl galima teigti, kad Teismui kol kas trūksta nuoseklumo taikant pagrindines teises ES prieglobsčio teisyno aiškinimo procese. $N$. S. byla rodo, kad ESTT yra pasiruošęs visiškai pasikliauti Strasbūro teismo praktika, aiškindamas Dublino reglamento nuostatas. Šiuo žingsniu ESTT 
iš esmės parodė pasiryžimą suteikti ES teisès sistemos saugomam negrąžinimo principui EŽTT praktiką atitinkantị turinį. Nepaisant akivaizdžių šio požiūrio privalumų, jis gali suponuoti kazuistinį negrąžinimo principo aiškinimą ES teisèje ir neleisti ,atsiskleisti““ kitoms Chartijos nuostatoms, pirmiausia teisę i prieglobstị įtvirtinančiam Chartijos 18 straipsniui. Nors ESTT iki šiol išnagrinèjo tik vieną bylą dẻl papildomos apsaugos, tikètina, kad EŽTT praktika taikant EŽTK 3 straipsnị darys didelę įtaką šiam institutui, ypač Kvalifikavimo direktyvos 15 straipsnio $a$ ir $b$ punkto nuostatoms. Iki šiol išnagrinètos bylos rodo, kad ESTT yra pasiruošęs naudotis Chartijos potencialu aiškinandams pabėgèlio sąvokos požymius bei prieglobsčio procedūroms taikytinus reikalavimus, tarp jų - ir teisę ị veiksmingą teisès gynimo priemonę. Nors šioje srityje EŽTT praktikai gali atitekti kuklesnis vaidmuo, ji gali būti svarbiu referencijos šaltiniu aiškinant atskiras Kvalifikavimo ir Prieglobsčio procedūrų direktyvos nuostatas, pirmiausia vidaus apsaugos ar persekiojimo vykdytojų koncepcijas bei skundo suspensyvinio poveikio aspektus.

3. Palyginus EŽTK ir ES teisių gynimo mechanizmą galima daryti išvadą, kad didžiausias EŽTK privalumas yra galimybè prieglobsčio prašytojui pateikti individualią peticiją, kas nèra įmanoma ESTT bylose. Ne mažiau svarbi ir solidi EŽTT jurisprudencija dèl kai kurių teisių gynimo, suformulavusi ir įtvirtinusi konkrečius prieglobsčio teisès kriterijus (nevalstybiniai persekiojimo subjektai, vidaus apsauga) bei esanti ES teisès pagrindu (papildoma apsauga) arba jos tobulinimo paskata (suspensyvinis skundo poveikis). Būtent EŽTK dèka atsirado reali galimybė ginčyti ES teisès nuostatas, kurios prieštarauja žmogaus teisėms (Dublino reglamentas). Nors EŽTK nèra specifinis prieglobsčio teisių gynimo mechanizmas ir nusileidžia ESTT igaliojimų spręsti konkrečius prieglobsčio teisės klausimus prasme bei akivaizdžiai procedūrų operatyvumo požiūriu, kuriuo pasižymi ESTT, pastaruoju metu vis labiau taikoma pilotinių sprendimų procedūra padeda spręsti ne tik labai konkrečias prieglobsčio prašytojų teisių apsaugos problemas, bet ir nurodo bendras gaires valstybėms dèl sisteminių žmogaus teisių apsaugos problemų sprendimo. Taigi abi jurisdikcijos žymiai sustiprina prieglobsčio teisių gynimo galimybes bei formuoja bendrą oazę prieglobsčio prašytojams Europoje.

\section{Literatūra}

\section{Teisès aktai ir ju projektai}

Europos Sajungos pagrindinių teisių chartija [interaktyvus]. [žiūrèta 2013-07-30]. <http://eurlex.europa.eu/lt/treaties/dat/32007X1214/ $\mathrm{htm} / \mathrm{C} 2007303 \mathrm{LT} .01000$ 101.htm>.

Pasiūlymas Europos Parlamento ir Europos Tarybos direktyvai dèl trečiujų šalių piliečiu ar asmenų be pilietybès priskyrimo prie tarptautinès apsaugos gavejų bei jų statuso ir suteikiamos apsaugos pobūdžio būtiniausių reikalavimų (nauja redakcija). [2009] COM 551.
Tarybos direktyva 2003/9/EB, nustatanti minimalias normas dẻl prieglobsčio prašytojų priemimo. [2003] O L31/18.

Sutarties dèl Europos Sajungos veikimo suvestinè redakcija. [2008] OL LTC 115/47.

2013 m. birželio 26 d. Europos Parlamento ir Tarybos direktyva 2013/33/ES, kuria nustatomos normos dèl tarptautinès apsaugos prašytojų prièmimo. [2013] OL L180, p. $96-116$.

2013 m. birželio 26 d. Europos Parlamento ir Tarybos direktyva 2013/32/ES dèl tarptautinès 
apsaugos suteikimo ir panaikinimo bendros tvarkos. [2013] OL L180, p. 60-95.

2013 m. birželio 26 d. Europos Parlamento ir Tarybos reglamentas (ES) Nr. 604/2013, kuriuo išdèstomi valstybès narès, atsakingos už trečiosios šalies piliečio arba asmens be pilietybės vienoje iš valstybių narių pateikto tarptautinès apsaugos prašymo nagrinejjimą, nustatymo kriterijai ir mechanizmai. [2013] OL L180, p. 31-59.

2011 m. gruodžio 13 d. Europos Parlamento ir Tarybos direktyva 2011/95/ES dèl trečiuju šalių piliečių ar asmenų be pilietybės priskyrimo prie tarptautinès apsaugos gavejų, vienodo statuso pabėgèliams arba papildomą apsaugą galintiems gauti asmenims ir suteikiamos apsaugos pobūdžio reikalavimų. [2011] OL L337, p. 9-26.

2008 m. gruodžio 16 d. Europos Parlamento ir

Tarybos direktyva 2008/115/EB dẻl bendru nelegaliai esančių trečiųjų šalių piliečių grąžinimo standartų ir tvarkos valstybėse narèse. [2008] OL L348, p. 98-107.

2005 m. gruodžio 1 d. Tarybos direktyva 2005/85/EB, nustatanti būtiniausius reikalavimus dèl pabėgèlio statuso suteikimo ir panaikinimo tvarkos valstybèse narèse. [2005] OL L326, p. 13-34; [2006] OL L175M, p. $168-189$.

2004 m. balandžio 29 d. Tarybos direktyva 2004/83/EB dèl trečiujų šalių piliečių ar asmenų be pilietybès priskyrimo pabėgèliams ar asmenims, kuriems reikalinga tarptautiné apsauga, jų statuso ir suteikiamos apsaugos pobūdžio būtiniausių standartų. [2004] OL L304, p. 2-2. Specialusis leidimas lietuviu kalba: 19 skyrius, 07 tomas, p. 96-107.

$2003 \mathrm{~m}$. vasario $18 \mathrm{~d}$. Tarybos reglamentas (EB) Nr. 343/2003, nustatantis valstybès narès, atsakingos už trečiosios šalies piliečio vienoje iš valstybių narių pateikto prieglobsčio prašymo nagrinejjimą, nustatymo kriterijus ir mechanizmus. [2003] OL L50, p. 1-10. Specialusis leidimas lietuvių kalba: 19 skyrius, 06 tomas, p. 109-118.

\section{Bylos}

EŽTT sprendimai

$A$ and Others v. United Kingdom [GC], no. 3455/05, ECHR 2009.

Abdolkhani and Karimnia v. Turkey, no. 30471/08, 22 September 2009.

Ahmed v. Austria, 17 December 1996, Reports of Judgments and Decisions 1996-VI.

Amrollahi v. Denmark, no. 56811/00, 11 July 2002.

Amuur v. France, 25 June 1996, Reports of Judgments and Decisions 1996-III.

Aoulmi v. France, no. 50278/99, ECHR 2006-I (extracts).

Aswat v. the United Kingdom, no. 17299/12, 16 April 2013.

Baysakov and Others v. Ukraine, no. 54131/08, 18 February 2010.

Chahal v. the United Kingdom, 15 November 1996, Reports 1996-V.

Čonka v. Belgium, no. 51564/99, ECHR 2002-I.

D. v. the United Kingdom, 2 May 1997, Reports of Judgments and Decisions 1997-III.

D. H. v. Finland (dec.), no. 30815/09, 28 June 2011.

Darren Omoregie and Others v. Norway, no. 265/07, 31 July 2008.

Gebremedhin [Gaberamadhien] v. France, no. 25389/05, ECHR 2007-II.

Geleri v. Romania, no. 33118/05, 15 February 2011.

Gül v. Switzerland, 19 February 1996, Reports 1996-I.

Hilal v. the United Kingdom, no. 45276/99, ECHR 2001-II.

Hirsi Jamaa and Others v. Italy, no. 27765/09, European Court of Human Rights, Judgement, 23 February 2012. Hirsi Jamaa and Others v. Italy [GC], no. 27765/09, ECHR 2012.

H. L. R. v. France, 29 April 1997, Reports 1997-III.

Hode and Abdi v. the United Kingdom, no. 22341/09, 6 November 2012.

I. K. v. Austria, no. 2964/12, 28 March 2013.

I. M. v. France, no. 9152/09, 2 February 2012.

Iskandarov v. Russia, no. 17185/05, 23 September 2010. 
Jabari v. Turkey, no. 40035/98, ECHR 2000VIII.

K. R. S. v. United Kingdom (dec.), no. 32733/08, 2 December 2008.

Labsi v. Slovakia, no. 33809/08, 15 May 2012.

Mamatkulov and Askarov v. Turkey [GC], nos. 46827/99 and 46951/99, ECHR 2005-I.

Mo. M. v. France, no. 18372/10, 18 April 2013.

Mohammed v. Austria, no. 2283/12, 6 June 2013.

Muskhadzhiyeva and Others v. Belgium, no. 41442/07, 19 January 2010.

M. S. S. v. Belgium and Greece [GC], no. 30696/09, ECHR 2011.

Mubilanzila Mayeka and Kaniki Mitunga v. Belgium, no. 13178/03, ECHR 2006-XI.

Muminov v. Russia, no. 42502/06, 11 December 2008.

N. v. Finland, no. 38885/02, 26 July 2005.

N. v. Sweden, no. 23505/09, 20 July 2010.

$N$. v. the United Kingdom [GC], no. 26565/05, ECHR 2008.

NA. v. the United Kingdom, no. 25904/07, 17 July 2008.

Nasrulloyev v. Russia, no. 656/06, 11 October 2007.

Nnyanzi v. the United Kingdom, no. 21878/06, 8 April 2008.

Popov v. France, nos. 39472/07 and 39474/07, 19 January 2012.

Othman (Abu Qatada) v. the United Kingdom, no. 8139/09, ECHR 2012 (extracts).

Rahimi v. Greece, no. 8687/08, 5 April 2011.

Riad and Idiab v. Belgium, no. 29787/03 and 29810/03, 24 January 2008.

Saadi v. Italy [GC], no. 37201/06, ECHR 2008.

Saadi v. the United Kingdom [GC], no. 13229/03, ECHR 2008.

Salah Sheekh v. the Netherlands, no. 1948/04, 11 January 2007.

Samsam Mohammed Hussein and Others v. the Netherlands and Italy (dec.), no. 27725/10, 2 April 2013.

S. F. and Others v. Sweden, no. 52077/10, 15 May 2012.

Sidikovy v. Russia, no. 73455/11, 20 June 2013. S. D. v. Greece, no. 53541/07, 11 June 2009.

Soering v. the United Kingdom, 7 July 1989, Series A No. 161.
Sufi and Elmi v. the United Kingdom, nos. 8319/07 and 11449/07, 28 June 2011.

Sultani v. France, no. 45223/05, ECHR 2007IV (extracts).

Tabesh v. Greece, no. 8256/07, 26 November 2009.

T. I. v. the United Kingdom (dec.), no. 43844/98, ECHR 2000-III.

Vilvarajah and Others v. the United Kingdom, 30 October 1991, Series A no. 215.

Y. P. and L. P. v. France, no. 32476/06, 2 September 2010.

ESTT sprendimai

Sujungtos bylos C-178/08 ir C-179/08, Aydin Salahadin Abdulla (C-175/08), Kamil Hasan (C-176/08), Ahmed Adem, Hamrin Mosa Rashi (C-178/08) ir Dler Jamal (C-179/08) v. Bundesrepublik Deutschland [2010] ETA I-01493.

Byla C-69/10, Brahim Samba Diouf prieš Ministre du Travail, de l'Emploi et de l'Immigration [2011] ETA I-07151.

Sujungtos bylos C-57/09 ir C-101/09, Bundesrepublik Deutschland prieš B (C-57/09) ir D (C-101/09) [2010] ETA I-10979.

Sujungtos bylos C-71/11 ir C-99/11, Bundesrepublik Deutschland prieš $Y(\mathrm{C}-71 / 11)$ ir Z (C-99/11) [2011] OL C 130 [2011] OL C $173,2012 \mathrm{~m}$. rugsejo $5 \mathrm{~d}$. sprendimas.

Byla C-344/08, Criminal proceedings against Tomasz Rubach [2009] ETA I-07033.

Byla 29-69, Erich Stauder prieš City of Ulm Sozialamt [1969] ETA 00419.

Byla C-540/03, Europos Parlamentas prieš Europos Sajungos Taryba [2006] ETA I-05769.

Byla C-71/02, Herbert Karner IndustrieAuktionen GmbH prieš Troostwijk GmbH [2004] ETA I-03025.

Case 228/69, Internationale Handelsgesellschaft mbH v. Einfuhr und Vorratsstelle Getreide und Futtermittel [1970] ECR 01125.

Byla C-175/11, H. I. D. ir B. A. prieš Refugee Applications Commissioner ir kt. [2011] OL C 204, $2013 \mathrm{~m}$. sausio $31 \mathrm{~d}$. sprendimas.

Sujungtos bylos C-411/10 ir C-493/10, N. S. (C-411/10) prieš Secretary of State for the 
Home Department et M. E. ir kt. (C-493/10) prieš Refugee Applications Commissioner ir Minister for Justice, Equality and Law Reform [2010] OL C 274 [2011] OL C 13, $2011 \mathrm{~m}$. gruodžio $21 \mathrm{~d}$. sprendimas.

Byla C-245/11, K prieš Bundesasylamt [2011] OL C 269, 2012 m. lapkričio 6 d. sprendimas.

Byla C-277/11, M. M. prieš Minister for Justice, Equality and Law Reform, Ireland ir Attorney General [2012] ECR 00000.

Byla C-534/11, Mehmet Arslan prieš Policie ČR, Krajské reditelství policie Ústeckého kraje, odbor cizinecké policie [2012] OL C 65, $2013 \mathrm{~m}$. gegužès $30 \mathrm{~d}$. sprendimas.

Byla C-465/07, Meki Elgafaji and Noor Elgafaji prieš Staatssecretaris van Justitie [2009] ETA I-00921.

Byla C-94/00, Roquette Frères SA ir Directeur général de la concurrence, de la consommation et de la répression des fraudes [2002] ETA I-09011.

Byla C-357/09 PPU, Said Shamilovich Kadzoev (Huchbarov) [2009] ETA I-11189.

Byla C-648/11, The Queen, prašoma MA ir kiti prieš Secretary of State for the Home Department [2012] OL C 65, $2013 \mathrm{~m}$. birželio $6 \mathrm{~d}$. sprendimas.

\section{Specialioji literatūra}

Battjes, H. European Asylum Law and International Law, Koninklijke Brill NV, Leiden, The Netherlands 2006.

Biekša, L.; Siniovas, V. Sąžiningos ir veiksmingos prieglobsčio procedūros beieškant: Lietuvos pastangos igyvendinti Tarybos direktyvą 2005/85/EB. Etniškumo studijos. 2013, 1.

Fact sheet on Expulsions and extraditions, Press Unit, European Court of Human Rights, May 2013 [interaktyvus]. [žiūrèta 2013-0730]. <http://www.echr.coe.int/Documents/ FS_Expulsions_Extraditions_ENG.pdf $>$.

Fact sheet "Dublin cases", European Court of Human Rights, Press Unit, May 2013.

Facts heet „Dublin cases“, European Court of Human Rights, Press Unit, August 2010.
Facts heet „Pilot Judgements“, European Court of Human Rights, Press Unit, July 2013.

Fact sheet „Collective expulsions“, European Court of Human Rights, Press Unit, January 2013.

Fact sheet "Case-law concerning the EU“, European Court of Human Rights, Press Unit, May 2013.

Fact sheet „Extra-territorial jurisdiction“, European Court of Human Rights, Press Unit, June 2013.

Governments, applicants and their lawyers urged to co-operate fully with European Court, following "alarming rise" in requests to suspend deportation, Press Release No. 127, Registrar of the Court, European Court of Human Rights, 11.02.11.

Handbook on European law relating to asylum, borders and immigration, European Court of Human Rights and EU Fundamental Rights Agency, Luxembourg, 2013.

International Commission of Jurists, Workshop on Migration and Human Rights in Europe, Non-refoulement in Europe after M. S. S. v. Belgium and Greece, Summary and Conclusions, July 2011.

Jočienė, D. Pagrindinių teisių apsauga pagal Europos žmogaus teisių konvenciją ir Europos Sajungos teisę. Jurisprudencija. 2010, 3(121): 97-113.

Maurer-Kober, B. Presentation at the EJTN Seminar „Migration and Asylum Law“, Session II: The European Convention on Human Rights Articles 3 and 8 Overview of the ECHR and CJEU jurisprudence, 11-12 September 2012, Bucharest [interaktyvus]. [žiūrèta 2013-07-30]. <http://www.ejtn.net/ Documents/About\%20EJTN/Independent $\% 20$ Seminars/Session_II_ECHR_Article_3_and_8_WINTER_Karin_MAURER-KOBER_Bettina_Seminar_Migration_and_Asylum_Law_11_12_September_2012.pdf>.

Ktistakis, Y. Protecting Migrants under the European Convention of Human Rights and the European Social Charter. A Handbook 
for Legal Practitioners. Council of Europe Publishing, February 2013.

Peers, S.The second phase of the Common European Asylum System: A brave new world - or lipstick on a pig? April 2013, 7 p. [interaktyvus]. [žiūrèta 2013-07-29]. $<$ http://www.statewatch.org/analyses/no220-ceas-second-phase.pdf $>$.

Presidency Conclusions of the Cologne European Council of 3 and 4 June 1999, Annex IV [interaktyvus]. [žiūrèta 201307-29].<http://www.consilium.europa.eu/ ueDocs/cms_Data/docs/pressData/en/ec/ kolnen.htm $>$.

The Conscience of Europe: 50 Years of the European Court of Human Rights.

Twenty Guidelines of the Commitee of Ministers of the Council of Europe on Forced Return, September 2005.
UNHCR Manual on Refugee Protection and the European Convention on Human Rights, Regional Bureau for Europe, Department of International Protection, April 2003, updated August 2006 [interaktyvus]. [žiūrèta 201307-29]. $<$ http://www.refworld.org/pdfid/3f4c d5c74.pdf $>$.

Winter, K. Presentation at the EJTN Seminar „Migration and Asylum Law“, Session II: The European Convention on Human Rights Articles 3 and 8 Overview of the ECHR and CJEU jurisprudence, 11-12 September 2012, Bucharest, p. 15 [interaktyvus]. [žiūrèta 2013-07-29].<http://www.ejtn.net/Documents/ About $\%$ 20EJTN/Independent $\% 20$ Seminars/ Session_II_ECHR_Article_3_and_8 WINTER_Karin_MAURER-KOBER_ Bettina_Seminar_Migration_and_Asylum Law_11_12_September_2012.pdf>.

\title{
PROTECTION UNDER THE EUROPEAN CONVENTION ON HUMAN RIGHTS - OASIS FOR ASYLUM SEEKERS IN EUROPE?
}

\author{
Lyra Jakulevičienè, Vladimiras Siniovas \\ Mykolas Romeris University, Lithuania
}

Summary. Even though the Convention for the Protection of Human Rights and Fundamental Freedoms (ECHR) does not explicitly address the rights of asylum seekers and refugees, the case law of the European Human Rights Court (ECtHR) confirms that their rights can be successfully defended under this mechanism. In parallel, in its evolving jurisprudence on asylum the Court of Justice of the European Union (CJEU) refers to the Strasbourg case law, where there is a certain interrelationship between these two jurisdictions, in particular given the recent ECtHR pronouncement on "EU Dublin transfers". The article aims at evaluating protection available for asylum seekers and refugees under the ECHR, while comparing it with protection of asylum relevant fundamental rights under the EU legal order and the most recent jurisprudence of the CJEU in asylum cases. The authors also analyze which of the two systems is more favourable and what are their limitations. Thus, the article offers to students and practitioners a detailed analysis of ECtHR and CJEU jurisprudence in asylum cases through a comparative perspective, as well as the key problematic aspects arising in both jurisdictions and their junction. 
The jurisprudence of the ECtHR reveals that despite the most developed protection from expulsion under Article 3 of the ECHR, it does not sufficiently secure status for the concerned persons. Effective remedy requirements under the ECHR allow for filling the gaps of national asylum procedures, while recognition of vulnerability and special status of asylum seekers by the ECtHR assist in addressing still commonly prevailing detention problems of asylum seekers in Europe. In the context of family protection, the recognition of positive obligations by states to reunite the refugee families is still rudimentary, thus, clearly Article 3 protection in expulsion cases takes over Article 8. At the same time, the jurisprudence of the CJEU in asylum cases is still inconsistent, as the court sometimes takes decisions without including human rights into its' analysis (Kadzoev, Arslan, K.), while in other cases refers to the Charter (MA and others), verifies if its' own decision is in line with the ECtHR jurisprudence (Elgafaji) or shapes secondary legislation in line with Strasbourg arguments and findings (N.S.). Quite likely, the ECtHR practice will have an important influence on the developments of subsidiary protection in the EU, at least in the context of Articles 2 and 3 of the ECHR, and serve as an important reference for interpretation of various concepts under the EU Qualification and Procedures Directives. The comparative analysis of pros and cons of the two mechanisms demonstrates that the main advantage of the ECtHR is individual justice possibility, which is not yet accessible under CJEU preliminary judgement procedure and its input in developing asylum law concepts, such as non-state agents of persecution, internal protection or even subsidiary protection regime under $E U$ asylum law. Thanks to the $E C t H R$, the realistic possibility to question the application of certain EU norms has emerged (Dublin Regulation). While the ECtHR does not have such a specific competence over asylum issues as the CJEU and is clearly a slow and seriously overburdened mechanism, the pilot judgement procedure seems to be increasingly capable of providing guidelines to the states concerning systematic problems in their asylum procedures. Thus, both jurisdictions in their own ways contribute to strengthening asylum seekers' protection while forming a common oasis for these individuals in Europe.

Keywords: asylum, ECHR, request for preliminary ruling, Charter, EU asylum acquis.

Lyra Jakulevičienė, Mykolo Romerio universiteto Tarptautinès ir Europos Sajungos teisès instituto profesorè. Mokslinių tyrimų kryptys: tarptautinių sutarčių teisė, pabėgèlių teisè, žmogaus teisių apsauga.

Lyra Jakulevičienė, Mykolas Romeris University, International and European Union Law Institute, Professor. Research interests: international treaty law, refugee law, international protection of human rights.

Vladimiras Siniovas, Darnios visuomenès centras, prieglobsčio teisės ekspertas. Mokslinių tyrimų kryptys: prieglobsčio ir migracijos teisè, žmogaus teisių apsauga.

Vladimiras Siniovas, Asylum Law Expert, Centre for Sustainable Development. Research interests: asylum, migration and human rights law. 